\title{
Choice of Law and Minimal Scrutiny
}

\author{
Louise Weinberg†
}

One must approach with diffidence the subject of constitutional control of choice of law, a subject to which so many of our best conflicts writers have directed their thinking. ${ }^{1}$ But the Supreme Court's renewed interest in those peculiar problems of federalism lumped together under the heading of "the conflict of laws"2 invites fresh discussion of the extent to which the Constitu-

$\dagger$ Professor of Law, The University of Texas.

1 Notable recent articles include Martin, Constitutional Limitations on Choice of Law, 61 Connell L. Rev. 185 (1976), and Reese, Legislative Jurisdiction, 78 ColUm. L. Rev. 1587 (1978). Significant recent treatise treatments include R. Leplar, American Conflicts Law 105-23 (3d ed. 1977), and R. Weintraub, Commentary on the Conplict of Laws 495-547 (2d ed. 1980). Useful casebook discussions may be found in R. Cramton, D. Currie \& H. Kay, Conflict of Laws 403-52 (3d ed. 1981), and A. von Mehren \& D. Trautman, The law of Multistate Problems 1242-58 (1965). For earlier writing of continuing interest, see $B$. Currie, Selected Essays on the Conflict of Laws 188-360, 445-583 (1963).

2 On "minimum contacts" requirements for adjudicatory jurisdiction, see Stafford v. Briggs, 444 U.S. 527 (1980); Rush v. Savchuk, 444 U.S. 320 (1980); World-Wide Volkswagen Corp. v. Woodson, 444 U.S. 286 (1980); Kulko v. Superior Court, 436 U.S. 84 (1978); Shaffer v. Heitner, 433 U.S. 186 (1977). The Court had not been heard from on this question since Hanson v. Denckla, 357 U.S. 235 (1958).

On private interstate conflict of laws, see Allstate Ins. Co. v. Hague, 449 U.S. 302 (1981); Nevada v. Hall, 440 U.S. 410 (1979). The Court had not been heard from in this field since Crider v. Zurich Ins. Co., 380 U.S. 39 (1965).

On the effect of a state adjudication in the courts of a sister state, see Thomas v. Washington Gas Light Co., 448 U.S. 261 (1980). This appears to be the first case in this area since Durfee v. Duke, 375 U.S. 106 (1963).

The depth of dormancy during the interval should not be overstated. On notice for purposes of adjudicatory jurisdiction, see, e.g., Robinson v. Hanrahan, 409 U.S. 38 (1972); Schroeder v. City of New York, 371 U.S. 208 (1962). On prejudgment attachment, see, e.g., Mitchell v. W.T. Grant Co., 416 U.S. 600 (1974); Fuentes v. Shevin, 407 U.S. 67 (1972); Sniadach v. Family Fin. Corp., 395 U.S. 337 (1969). On jurisdiction by consent, see, e.g., Swarb v. Lennox, 405 U.S. 191 (1972); D.H. Overmyer Co. v. Frick Co., 405 U.S. 174 (1972); National Equip. Rental, Ltd. v. Szukhent, 375 U.S. 311 (1964). On ouster of federal jurisdiction by agreement, see The Bremen v. Zapata Off-Shore Co., 407 U.S. 1 (1972). For developments in interstate rendition, see, e.g., Pacileo v. Walker, 449 U.S. 86 (1980); Michigan v. Doran, 439 U.S. 282 (1978); Sweeney v. Woodall, 344 U.S. 86 (1952).

With respect to choice of law, there were cases too numerous for inclusion here on federal/state conflict of laws; extrastate applications of municipal law; discrimination against nonresidents; residency requirements; extraterritorial applications of United States laws; domicile of aliens; and the effects of foreign governmental actions in state and federal courts.

On the effect of federal judgments, see, e.g., Parklane Hosiery Co. v. Shore, 439 U.S. 322 
tion controls, or should control, choices of law.

Despite copious and distinguished commentary, it is fair to say that the consensus we may believe we have reached on the fundamentals of the subject is fragile, tenuous, and probably illusory. It is typical of the field that we tend to subsume all inquiries under a single, undifferentiated question: What are the constitutional "limits" on choice of law? ${ }^{3}$ For answer, we conclude that the Constitution $^{4}$ polices choices of law for reasonableness, ${ }^{5}$ fairness ${ }^{6}$ (by which we generally mean foreseeability ${ }^{7}$ ), and deference to principles of federalism and comity. ${ }^{8}$ But we tend to be quite cautious in connecting these concerns with reported decisions; the Supreme Court's inquiry, we suggest, must of necessity vary with the cases; what will be reasonable or fair in one context may be less so in another. ${ }^{\circ}$ We note that the Court's later decisions are concerned with the extent of a state's interest in applying its own law; ${ }^{10}$ want

(1979); Blonder-Tongue Laboratories, Inc. v. University of Ill. Found., 402 U.S. 313 (1971). On the effect of state judgments in federal courts, see, e.g., Allen v. McCurry, 449 U.S. 90 (1980); Wainwright v. Sykes, 433 U.S. 72 (1977); Stone v. Powell, 428 U.S. 465 (1976); Francis v. Henderson, 425 U.S. 536 (1976).

s See, e.g., R. Leflar, supra note 1, at 105; R. WeintrauB, supra note 1, at 495; Martin, supra note 1, at 185; Reese, supra note 1 , at 1587.

- Throughout this discussion I assume that it is unimportant which particular clause of the Constitution may be employed to strike down a choice of law. See Allstate Ins. Co. v. Hague, 449 U.S. 302, 321-22 (1981) (Stevens, J., concurring) ("I realize that both this Court's analysis of choice-of-law questions and scholarly criticism of those decisions have treated ... [ [full faith and credit and due process] inquiries as though they were indistinguishable.") (footnotes omitted). Justice Stevens went on to argue that the two clauses should protect different interests. Id. at 322, 326. Accord, R. WeINTRAUB, supra note 1 , at 495-547.

s R. Weintraub, supra note 1 , at 505.

- See R. Leflar, supra note 1, at 121-22 ("justifiable expectations" of the parties); R. WeiNTrauB, supra note 1, at 506 ("unfair surprise"); Martin, supra note 1, at 190 ("unfair surprise," " "justifiable expectations' of the parties"); Reese, supra note 1, at 1608 ("reliance and expectation").

7 E.g., Allstate Ins. Co. v. Hague, 449 U.S. 302, 327 (1981) (Stevens, J., concurring); id. at 333 (Powell, J., dissenting).

- See, e.g., R. LEFLAR, supra note 1, at 121 ("Respect for the interests of the states . . is a major element in the constitutional concept."); Martin, supra note 1, at 229 (insufficient to concentrate only on fairness of forum law; court also should consider "competing interests of other jurisdictions"); Reese, supra note 1, at 1608 (choice of law must be fair, but also "consistent with the needs of the federal . . . system").

- See, e.g., R. LerLar, supra note 1, at 121 ("The identification of unreasonableness requires a weighing of values .... There is no mathematical formula . ..."); $R$. WeINTraub, supra note 1, at 505 ("Any further elaborations of this 'reasonableness' standard are attempts to . . . facilitate its application to specific cases."); Martin, supra note 1, at 216 (the Court's "analysis ... entails an inherently uncertain weighing of competing state interests").

10 See, e.g., R. Leflar, supra note 1, at 118; R. Weintraub, supra note 1, at 519-23; 
of interest will render application of the state's laws unconstitutional. We conclude that this is because the application of a noninterested ${ }^{11}$ state's laws would be unreasonable, unfair, and would impinge on the concerns of sister states. ${ }^{12}$ But we find scant attention paid to reasonableness, fairness, and comity in these interestanalytic sorts of cases, and we are not entirely clear just how interest analysis reaches the "limits" we suppose to be imposed on a choice of law by the due process clause ${ }^{13}$ or the full faith and credit clause: ${ }^{14}$ reasonableness; fairness and foreseeability; comity and federalism. For this and other reasons, from time to time it is proposed that constitutional analysis should include additional inquiries concerning fairness or federalism issues. ${ }^{15}$ These suggestions are buttressed by occasional Supreme Court discussions of such issues. ${ }^{16}$ But candor should compel us to note that, despite all that has been written on the subject, among the modern cases we find not one in which the Court has struck down the choice of an interested state's laws on grounds of unreasonableness, unfairness, want of comity, or any other ground thought relevant to the field.17 Meanwhile, with this equipment, we continue to discuss the small

Reese, supra note 1, at 1600-06. See generally Currie, The Constitution and the Choice of Law: Governmental Interests and the Judicial Function, 26 U. CHI. L. REv. 9 (1958), reprinted in B. CuRRIE, supra note 1 , at 188; cases cited infra notes 55-58.

11 "Disinterested" carries an extraneous suggestion of impartiality and probably ought to be limited to the context of the "disinterested third state" in which Brainerd Currie used it. Currie, The Disinterested Third State, 28 Law \& Contemp. Pross. 754 (1963).

12 See, e.g., R. LefLAR, supra note 1, at 121; R. WeINTraUB, supra note 1, at 505-06; Reese, supra note 1, at 1597-99.

is U.S. ConsT. amend. XIV, § 1 ("nor shall any State deprive any person of life, liberty, or property, without due process of law").

14 Id. art. IV, § 1 ("Full Faith and Credit shall be given in each State to the public Acts, Records and judicial Proceedings of every other State.").

${ }^{15}$ See, e.g., Justice Stevens's concurrence in Allstate Ins. Co. v. Hague, 449 U.S. 302, 320 (1981) (proposing federalism test under full faith and credit clause and fairness test under due process clause); R. WeINTRAUB, supra note 1, at 527-28 (full faith and credit clause requires balancing of otherwise reasonable application of law against need for national uniformity of result); Martin, supra note 1, at 230 ("Progress lies . . . with a requirement that in applying its own law the state give proper regard to the interests of other states."); Reese, supra note 1, at 1592-94 (due process clause alone imposes two sets of limits, one having to do with fairness and one with federalism).

${ }^{16}$ E.g., Allstate Ins. Co. v. Hague, 449 U.S. 302, 321-32 (1981) (Stevens, J., concurring) (application of forum law foreseeable to defendant and sovereignty of sister state not offended); Clay v. Sun Ins. Office, Ltd., 377 U.S. 179, 182 (1964) (Clay II) (quoting with approval Justice Black's dissent in Clay v. Sun Ins. Office, Ltd., 363 U.S. 207, 221 (1960) (Clay I)) (application of forum law fair to defendant who "must have known that it might be sued there").

17 Hughes v. Fetter, 341 U.S. 609 (1951), is not to the contrary. See infra note 47. 
and increasingly irrelevant corpus of old-style Supreme Court conflicts cases; ${ }^{18}$ so does the Court, occasionally with disastrous effect upon any possibility of rationalizing the field. ${ }^{19}$ And we persist in categorizing and discussing these antiques under their respective legal subject matters, rendering improbable any general theoretical understanding. ${ }^{20}$

Now, amid these perplexities, we suddenly find the Court preparing some sort of change. Whatever its position on conflicts may have been, the Court now seems to be wavering in it. In its most recent attempt to grapple with the problem, Allstate Insurance Co. $v$. Hague, ${ }^{21}$ a fragmented Supreme Court seems to be searching for a new analysis that will somehow take in these additional concerns of fairness and federalism.

We find Justice Stevens suggesting that separate inquiries be made under the due process clause for fairness and under the full faith and credit clause for concerns of federalism and comity. ${ }^{22}$ Justice Powell, with whom the Chief Justice and Justice Rehnquist agree, proposes that a fairness inquiry be thrust into the initial stage of an interest analysis. ${ }^{23}$ Justice Brennan, whose view is shared by Justices White, Marshall, and Blackmun, does seem committed to a continuing policy of review for state governmental interest alone, ${ }^{24}$ but that position apparently will no longer invariably command a majority of the Court. ${ }^{25}$

At this impasse it seems reasonably certain that we will not advance our inquiry very much if we remain faithful to our current perceptions of its parameters. So I would like to offer a simple reformulation and clarification of the issues which I believe will provide a general analytic framework for understanding constitutional review in conflicts cases, and can help us reach a general theory of

18 R. Cramton, D. Currie \& H. Kay, supra note 1 , at 403-520, is unique in relegating most of this obsolete material to editorial summary.

10 See infra text accompanying notes $52-54$.

${ }^{20}$ The traditional arrangement of the field under separate substantive headings, such as "insurance cases," "compensation cases," and so on, continues to infuence the writing of all the writers cited supra note 1 , except for R. Cramton, D. Currie \& H. Kay.

21449 U.S. 302 (1981).

22 Id. at 320 (Stevens, J., concurring).

${ }^{28}$ Id. at 333 (Powell, J., dissenting).

24 Id. at 320.

2s Justice Brennan's opinion was joined by a plurality of the Court. Justice Stevens's concurrence was based on his conclusion that the application of forum law in Hague survived his proposed, more restrictive scrutiny. Justice Stewart, a member of the majority in Nevada v. Hall, 440 U.S. 410 (1979), did not sit in the Hague case, and has since left the Court. 
such review. This article, written in light of this general theoretical approach, will argue that neither fairness nor federalism has played any role in the Supreme Court's supervision of conflicts cases; that the Court in fact has employed a level of constitutional scrutiny in these cases akin to the "minimal scrutiny" used in other cases challenging the constitutionality of applications of state law; that a more refined or restrictive scrutiny would be inappropriate in view of fundamental national policy goals, and unworkable in view of constraints upon the Court in conflicts cases; and that the Supreme Court should therefore reject current proposals for tighter constitutional control over the choice-of-law process.

\section{A General Analytic Framework for Understanding Constitutional Review in Conflicts Cases}

Suppose we pluck up from the mass of disparate, undefined, and unseparated concepts having something to do with "limits" on choices of law the single, broad notion of lack of "interest," usually intended to convey that a state needs some rational basis for applying its laws. Let us give this concept the importance of a separate, affirmative heading and call it "power." By that we will mean the power of a state to regulate a particular controversy by its laws. The Supreme Court determines the existence of such power by considering whether the particular controversy falls within the state's legitimate sphere of interest or legislative concern.

Next, we will more narrowly define the class of remaining concepts, which includes such matters as reasonableness, fairness, and comity, as a class not simply of "limits," but of limits on the power of an interested state.

Finally, let us suppose that each of these two classes of concepts will be the object of its own distinct line of inquiry. On the question of "power," the inquiry will be limited to the narrow question whether the issue in controversy is within the sphere of legitimate legislative interest of the state whose law is sought to be applied. Whatever minimal degree of reasonableness, fairness, or comity the existence of a state governmental interest may imply, there is no inquiry under this heading for reasonableness, fairness, or comity as such. Our interest analysis will produce a conclusion with respect to power only. Under the second question, however, the question of "limits," the inquiry may concern itself with reasonableness, fairness, or comity beyond the minimum that the existence of acknowledged state power already implies. That is be- 
cause this second inquiry has to do with limits on the power of an interested state, not with limits on state power generally. This simple reorganization of the issues is not semantic juggling. It will enable us to construct a general theoretical framework for analyzing the problems of constitutional review of choices of law.

What we have done is to put interest in its correct relation to the constitutional question, as the source of state regulatory power, rather than as a disconnected concept that in some indirect way helps determine the limits upon that power. This is consonant with our understanding of the source of state lawmaking power in other contexts. ${ }^{28}$ The question of the existence of power can now be sorted out from the question of the wisdom or fairness of its exercise.

One consequence is that each inquiry is clarified in relation to the other. Given one inquiry about power, and a second inquiry about limits on the exercise of acknowledged power, we can now see that the second inquiry is subordinate to and dependent upon the first. If a state lacks legislative power, questions of the wisdom or fairness of the exercise of its power simply cannot arise. ${ }^{27}$ It will be of no constitutional consequence, then, that an application of a noninterested state's laws is also unfair: interest analysis preliminarily will have revealed the application to be arbitrary and unreasonable; thus, the application already will have been struck down.

It becomes apparent that this second inquiry, concerning limits on the power of an interested state, cannot be brought into play even where the forum has power, if the forum is the only interested state. Where the forum is the only such state, no other state's laws may be applied constitutionally, and therefore no question of want of comity or of contrary expectation can arise. Thus, this second inquiry concerning "limits" has meaning only in

28 That is, the "acknowledged power of a state to regulate its police, its domestic trade, and to govern its own citizens." Gibbons v. Ogden, 22 U.S. (9 Wheat.) 1, 208 (1824) (economic regulations affecting interstate commerce). There seems little fundamental difference between the police power and other formulations. All are summarized by the statement that the source of state legislative power is the state's governmental interest, and the limit on the exercise of that power is some conflicting national policy. With respect to economic regulation affecting liberty of contract, see Nebbia v. New York, 291 U.S. 502, 509 (1934); Lochner v. New York, 198 U.S. 45, 65 (1905) (Harlan, J., dissenting). With respect to a choice of law affecting liberty of contract, see New York Life Ins. Co. v. Dodge, 246 U.S. 357, 377-78, 38283 (1918) (Brandeis, J., dissenting). See also, with respect to the power of a state to reach extraterritorial events within its sphere of interest, Skiriotes v. Florida, 313 U.S. 69 (1941).

${ }^{27}$ Justice Stevens pointed this out in Allstate Ins. Co. v. Hague, 449 U.S. 302, 320 n.3 (1981) (concurring opinion). 
the so-called "true conflict"28 case, in which the concerned sovereigns have conflicting policies that would be advanced by application of their respective laws to the particular controversy.

We can now discern theoretical levels of constitutional scrutiny of choice of law, similar to those found in other areas of constitutional law: minimal scrutiny, ${ }^{29}$ which can only review as arbitrary and unreasonable the choice of a noninterested state's laws in a false conflict case and will always sustain the choice of an interested state's laws in a true conflict case; ${ }^{30}$ and restrictive scrutiny, ${ }^{31}$ which can review the choice of an interested state's laws for such deficiencies of reasonableness, fairness, or comity as the Supreme Court might further determine to control in cases of true conflict.

We now can begin to distinguish between the minimal reasonableness, fairness, or comity that minimal scrutiny requires, and the sort of reasonableness, fairness, or comity that restrictive scrutiny would require. The distinction emerges with nice clarity. Cases raising issues appropriate for restrictive review ${ }^{32}$ might include, for example, cases in which the defendant's conduct was au-

28 Currie, Married Women's Contracts: A Study in Conflict-of-Laws Method, $25 \mathrm{U}$. CHI. L. REv. 227, 258-59 (1958), reprinted in B. CuRRIE, supra note 1, at 77, 116-17.

29 With respect to minimal scrutiny under the due process clause, see United States v. Carolene Products Co., 304 U.S. 144, 152 (1938) (state laws must have "some rational basis"); West Coast Hotel Co. v. Parrish, 300 U.S. 379, 399 (1937) (state law must not be "arbitrary or capricious"). With respect to minimal scrutiny under the equal protection clause, see City of New Orleans v. Dukes, 427 U.S. 297, 303 (1976) (per curiam) (classification must be "rationally related to a legitimate state interest"), overruling Morey v. Doud, 354 U.S. 457 (1957); Lindsley v. Natural Carbonic Gas Co., 220 U.S. 61, 78 (1911) (classification must have "some reasonable basis" and not be "purely arbitrary"). Professor Sedler has brought an interesting historical insight to his analysis of the constitutional position, and reached a similar conclusion in Sedler, Constitutional Limitations on Choice of Law: The Perspective of Constitutional Generalism, 10 Horstra L. REv. 59 (1981). Professor Sedler's article was made available to me after this article had been accepted for publication.

so This is a theoretical statement only. See infra note 39.

s1 I do not mean to haul out the big guns reserved for fundamental rights, see Griswold v. Connecticut, 381 U.S. 479 (1965) (right of marital privacy), or for inherently suspect classifications, see Loving v. Virginia, 388 U.S. 1 (1967) (racial classification). See also United States v. Carolene Products Co., 304 U.S. 144, 152 n.4 (1988). Other tiers of equal protection review also seem wide of the mark, generally focusing upon the degree of state interest. See generally Gunther, Foreword: In Search of Evolving Doctrine on a Changing Court: $A$ Model for a Newer Equal Protection, 86 HaRv. L. REv. 1 (1972); Tussman \& tenBroeck, The Equal Protection of the Laws, 37 CaLIF. L. REv. 341 (1949). The restrictive scrutiny here identified posits a specialized inquiry into the fairness and comity of an act of an interested state. It is thus best discussed in its own terms. If, however, an analogy would be helpful, the closest may be review under the commerce clause of the act of an interested state. See, e.g., Bibb v. Navajo Freight Lines, Inc., 359 U.S. 520 (1959).

${ }^{32}$ Examples are discussed infra part III-D. 
thorized or protected by the laws of an interested state where the defendant acted; cases in which a party moved unilaterally and unforeseeably to the forum state after the transaction or occurrence giving rise to the litigation; cases in which the validity of a contract, trust, devise, or marriage, or the legitimacy of a birth, was called in question solely because of a contact with an interested invalidating state; cases in which the plaintiff was forced to a defendant-favoring forum; and cases in which the defendant is a state. These cases seem to be candidates for restrictive review because in them the fact of the forum's interest alone may not of itself resolve the problems of fairness or comity presented: the lack of foreseeability of the choice of law on the part of the regulated party in the first two examples, and disturbances in the functioning of the multistate system in all of them.

If in conjunction with this reformulation we refer to discerned national policies bearing upon interstate litigation and to technical considerations bearing on the feasibility of review, we will have a general theory of constitutional review of conflicts cases, with power to resolve the question whether minimal or restrictive scrutiny should furnish the level of review; and, if the former, to resolve in various contexts the question whether some exception might be made to the general rule of minimal scrutiny.

In sum, then, state governmental interest is the source of state legislative power. Minimal scrutiny of a choice of law under the Constitution will operate to strike down the application of a noninterested state's laws as arbitrary and unreasonable. Application of an interested state's laws can be struck down on grounds of unreasonableness, unfairness, want of comity, or other defect only through restrictive review. Policy and functional considerations relevant to the field suggest that in conflicts cases, review should be limited to minimal scrutiny for state interest alone.

\section{The Settred Position: Minimal Scrutiny of State Choices OF LAW}

What are the constitutional limits on state choices of law? When the question is put in that capacious way, particularly if two or three unreconstructedly territorialist cases (in which a choice of law actually may have been struck down) ${ }^{3 s}$ are thrown into the hopper, it will not be wholly inaccurate to conclude, as writers tend 
variously to do, ${ }^{34}$ that the Constitution polices state choices of law for fairness or reasonableness or comity. But this conclusion will be somewhat misleading.

Once the problem is examined from the general viewpoint outlined in the previous section, one's way of stating existing law on this question will undergo a rather striking transformation. For it has been, or ought to have been, clear since the great watershed opinions of Justice Stone in Alaska Packers ${ }^{36}$ and Pacific Employ$e r s^{36}$ that there are, in fact, no limits whatsoever on the choice of an interested state's laws. It will, indeed, be familiar learning to toilers in these vineyards that under Pacific Employers, an interested state generally may apply its own laws in its own courts, just as it is understood that under the rule of Home Insurance Co. $v$. Dick, ${ }^{37}$ a noninterested state generally may not. Under Dick, application of a noninterested state's laws will be struck down as arbitrary and unreasonable. Scrutiny for the minimal interest that empowers a state to regulate has become, precisely, minimal scrutiny. There is no peg beyond "arbitrary or unreasonable"s8 on which to hang a constitutional question. ${ }^{38}$

Of course, a minimum of fairness and reasonableness will always be assured by a process that weeds out the arbitrary and unreasonable; and serious offense to principles of comity or federalism is unlikely to be offered by application of minimally reasonable, nonarbitrary law. But it is essential to appreciate that the level of review employed by the Supreme Court nonetheless has been that of minimal scrutiny.

It must be conceded that the revolution launched by Pacific Employers did not happen all at once. One cannot point to an un-

${ }^{34}$ See supra notes 5-8 and accompanying text.

${ }^{35}$ Alaska Packers Ass'n v. Industrial Accident Comm'n, 294 U.S. 532 (1935). Stone became Chief Justice in 1941.

${ }^{36}$ Pacific Employers Ins. Co. v. Industrial Accident Comm'n, 306 U.S. 493 (1939).

37281 U.S. 397 (1930).

${ }^{38}$ This was the phrase employed by Justice Stone in Alaska Packers, 294 U.S. at 542.

${ }^{39}$ This is not to say that actual Supreme Court decisions will always fall into one category or the other. The Court has been notably reluctant to strike down the application of a noninterested state's law where a traditional choice-of-law rule has pointed to the result, see, e.g., Day \& Zimmermann, Inc. v. Challoner, 423 U.S. 3 (1975) (per curiam) (foreign law), and has struck down application of an interested state's law where a uniform choice rule seemed preferable, see, e.g., Order of United Commercial Travelers v. Wolfe, 331 U.S. 586 (1947). But for purposes of this article, state "interest" under constitutional scrutiny may be understood as fully congruent with state "interest" under a standard interest analysis used to resolve a conflict of laws in the first instance. See supra note 30; infra text accompanying notes 50-51. 
interrupted course of minimal-scrutiny decisions, all reasoned on modern, functional lines. There was, notably, the problem of Alaska Packers to be dealt with: the problem of the false start. For in Alaska Packers, Justice Stone had correctly identified the source of state regulatory power to be governmental interest, but had cluttered up this perception with the suggestion that the Court would weigh conflicting state interests in making its allocation of regulatory power between the competing states. ${ }^{40}$ This notion of interest-weighing was profoundly inconsistent with Stone's perception, in the same case, that an interested state ought not to be required in its own courts to defer to the laws of some other interested state. ${ }^{41}$ If an interested state is free to apply its own laws in its own courts, some other state's interest cannot make a difference to the essential freedom of the forum. The weighing, in short, if desirable, was for the forum, not the Supreme Court. But language about interest-weighing cropped up in the reports long after Pacific Employers.

It was, moreover, to be expected that ingrained habits of thought should persist. In Order of United Commercial Travelers $v$. Wolfe, ${ }^{43}$ the Court bowed to the force of Bealean systematics" as late as 1947 , actually reaching a determinate holding that the laws of the state of incorporation must govern actions against fraternal benefit societies. Justice Burton, for the Court, buttressed his view with a reference to Alaska Packers, opining that the forum's interest in Wolfe did not "equal" the interest of the state where the defendant was incorporated. ${ }^{45}$ But although the Court

10 294 U.S. at 547. See also Freund, Chief Justice Stone and the Conflict of Laws, 59 HaRv. L. Rev. 1210, 1221-22 (1946).

11294 U.S. at 546-48.

42 See Order of United Commercial Travelers v. Wolfe, 331 U.S. 586, 623-24 (1947). There is a suggestion of interest-weighing, perhaps inadvertent, in Watson v. Employers Liab. Assurance Corp., 348 U.S. 66, 73 (1954). See also Pink v. AAA Highway Express, Inc., 314 U.S. 201, 210 (1941) ("When such conflict . . . arises, it is for this Court to resolve it by determining how far the full faith and credit clause demands the qualification or denial of rights asserted under the laws of one state. . . by the public acts and judicial proceedings of another.") (citing Alaska Packers).

is 331 U.S. 586 (1947).

"See 1-3 J. Beale, A Treatise on the Conflict of Laws (1935); Restatzment of Conflict of LAWS (1934).

6s 331 U.S. at 624. Wolfe followed a line of pre-Alaska Packers cases dealing with fraternal benefit societies. Modern Woodmen of America v. Mixer, 267 U.S. 544 (1925); Supreme Council of the Royal Arcanum v. Green, 237 U.S. 531 (1915). But see Supreme Lodge, Knights of Pythias v. Meyer, 198 U.S. 508 (1905) (sustaining doctor-patient privilege under forum law despite waiver valid under laws of place of contracting). See also the dictum on choice of law in the judgments case of Sovereign Camp of the Woodmen of the 
has since resorted to determinate choice rules in certain interstate conflicts cases within its original jurisidiction, ${ }^{46}$ Wolfe now seems irrelevant in ordinary conflicts cases, a post-Alaska Packers sport in our law. ${ }^{47}$

Moreover, and at some cost, the Court appears to have evaded the ultimate confrontation with the traditional rules: the problem of the false conflict. ${ }^{48}$ In cases in which the laws of the place of injury, for example, would bar the plaintiff, and where the law of the forum would assist the plaintiff's case, the forum is the only interested state. ${ }^{49}$ If constitutional interest analysis were fully congruent with ordinary conflicts interest analysis, the laws of the place of injury could not constitutionally be applied in this situation. But so unwilling has the Court been to declare unconstitutional an application of traditional choice rules that in no modern case has it sustained an application of forum law, as against the law of the (noninterested) place of injury, on the ground that the forum was the only interested state. ${ }^{60}$ In a 1975 diversity case accepted for review on another ground, the Court ignored the consti-

World v. Bolin, 305 U.S. 66, 78 (1938); under Fauntleroy v. Lum, 210 U.S. 230 (1908), of course, an erroneous choice of law is not a ground for impeachment of the judgment of a sister state.

${ }^{6}$ Pennsylvania v. New York, 407 U.S. 206 (1972); Texas v. New Jersey, 379 U.S. 674 (1965).

47 Both Hughes v. Fetter, 341 U.S. 609 (1951), and First Nat'l Bank v. United Air Lines, Inc., 342 U.S. 396 (1952), might be viewed as similarly aberrational applications of the full faith and credit clause after Alaska Packers. But these cases are consistent with minimal scrutiny; the applications of forum law that operated in these cases to exclude an arbitrarily selected class of state residents from recovery for wrongful death lacked a legitimate rational basis. The Court attempted to put Hughes and the United Air Lines case on this sort of footing when it explained in Wells v. Simonds Abrasive Co., 345 U.S. 514, 518-19 (1953), that "[ $t$ ] he crucial factor in [Hughes and United Air Lines] was that the forum laid an uneven hand on causes of action arising within and without the forum state." The effect of the discrimination was to deny survivors of those residents killed out of state the remedy available to survivors of residents killed in the state. See generally Currie, The Constitution and the "Transitory" Cause of Action, 73 HARv. L. REv. 36, 68 (1959), reprinted in B. Currie, supra note 1 , at 283,308 . The place where the injury occurred is in fact of no concern to a state providing compensation to injured residents. Cardillo v. Liberty Mut. Ins. Co., 330 U.S. 469 , 476 (1947).

${ }^{48}$ See generally Currie, supra note 28, at 251-54, reprinted in B. CurrIE, supra note 1, at $107-10$.

48 The place of injury's deterrent interests as well as its interests in recovering clean-up costs and the expenses of its medical creditors cannot be vindicated by a defendant-protecting rule. In addition, where the defendant is not a resident of the place of injury, that state has no interest in the application of its defendant-protecting rules. See generally $\mathrm{R}$. WEINTRAUB, supra note 1 , at $266-93$.

so In some of its workers' compensation cases the Court seems to have side-stepped the issue by avoiding inquiry into the interests of nonforum states. See infra notes 57, 78. 
tutional question implicit in the contemplated traditional choice of the law of the (noninterested) place of injury. ${ }^{\mathrm{s1}}$ The consequence is that constitutional conflicts law cannot be rationalized fully along interest-analytic lines.

Not the least among these persistent problems is the fact that the old-style cases, though dead, continue to rule us from their graves. Their influence has made it difficult for the Court, as well as the commentators, to deal rationally with recurring issues in the conflict of laws. All eight sitting Justices in the Hague case, ${ }^{52}$ for example, agreed, based on a profoundly obsolete 1936 opinion, ${ }^{\text {ss }}$ to the rather unreal proposition that the state to which the plaintiff had moved (after her claim arose but before trial) had insufficient interest in her welfare to enable it to regulate in her behalf the recalcitrant defendant within its jurisdiction..$^{54}$

These peculiar difficulties aside, after Pacific Employers we do find a series of conflicts cases ranging in time from 1939 to 1965 in

s1 Day \& Zimmermann, Inc. v. Challoner, 423 U.S. 3 (1975).

s2 449 U.S. 302 (1981).

ss John Hancock Mut. Life Ins. Co. v. Yates, 299 U.S. 178 (1936). In Yates, the forum's choice of its own law favoring the widow-beneficiary suing on a life insurance policy was struck down because the forum failed to give full faith and credit to the laws of the place of contracting. This holding is so Bealean that modern discussions usually treat the case as if it had been decided on due process grounds, pointing out, as the Yates Court had in its description of the facts, $i d$. at 179, that the forum's only connection with the case was as the after-acquired residence of the widow. See, e.g., Allstate Ins. Co. v. Hague, 449 U.S. 302, 333 n.4 (1981) (Stevens, J., concurring); R. WeINTraus, supra note 1, at 506.

s4 For a more realistic view, see, e.g., Lettieri v. Equitable Life Assurance Soc'y, 627 F.2d 930, 934 (9th Cir. 1980) (state of after-acquired residence of life insurance beneficiary can apply its own law to allow proof that preexisting condition was known to insurer). See also Clay v. Sun Ins. Office, Ltd., 377 U.S. 179, 180-83 (1964) (Clay II) (after-acquired residence may void contractual limitation on time in which suit could be brought, valid at place of contracting; insured-against risk also occurred at after-acquired residence); Hanson v. Denckla, 357 U.S. 235, 253 (1958) (dictum) (after-acquired residence of decedent settlor might constitutionally apply its own law to determine validity of trust settled in another state). See generally Currie, Conflict, Crisis and Confusion in New York, 1963 Duke L.J. 1, reprinted in B. CuRRIE, supra note 1, at 690; Note, Post Transaction or Occurrence Events in Conflict of Laws, 69 CoLUM. L. REv. 843 (1969). Professor Leflar implies that the forum's governmental interests are to be measured at the time of trial. R. LEPLAR, supra note 1, at 221. See also R. WEINTRAUB, supra note 1, at 331 ("there is no reason why post-accident changes in residence should not be considered insofar as they affect state-interest analysis"); Sedler, The Governmental Interest Approach to Choice of Law: An Analysis and a Reformulation, 25 U.C.L.A. L. REv. 181, 236-42 (1977) ("[T] he interests of the involved states should generally be determined as they exist at the time the case is presented to the court, and when subsequent changes in residence produce a mix of interests different from those existing at the time of the transaction, the new interests should be the ones considered by the court."). These writers variously recognize exceptions for unfairness, for rules that threaten to chill freedom of interstate movement, or for forum shopping. 
which the Court relied substantially and with increasing confidence upon minimal scrutiny for state interest alone. ${ }^{.5}$ The Court then fell silent in conflicts cases until 1979, when, in Nevada v. Hall, ${ }^{56}$ minimal scrutiny re-emerged full-blown and in modern dress. The series forms a vivid display of the extent to which the Court has been willing to tolerate parochial applications of forum law. Most of these are hard cases indeed-true conflicts, in which the Court permitted the interested forum to override the laws of another interested state. ${ }^{57}$ The series thus exhibits an impressive commitment to minimal scrutiny - a reluctance to use fairness or comity as checks upon law chosen on some rational basis.

It is true that in 1980 a doubtful note was struck in the case of Allstate Insurance Co. $v$. Hague. ${ }^{\mathrm{s}}$ There, the minimal-scrutiny opinion for the Court was able to muster only a plurality of the Justices. ${ }^{59}$ As it stands, of course, Hague represents only the last of

ss Besides Alaska Packers and Pacific Employers these include Klaxon Co. v. Stentor Elec. Mfg. Co., 313 U.S. 487 (1941); Griffin v. McCoach, 313 U.S. 498 (1941); Cardillo v. Liberty Mut. Ins. Co., 330 U.S. 469 (1947); Wells v. Simonds Abrasive Co., 345 U.S. 514 (1953); Watson v. Employers Liab. Assurance Corp., 348 U.S. 66 (1954); Carroll v. Lanza, 349 U.S. 408 (1955); Clay v. Sun Ins. Office, Ltd., 377 U.S. 179 (1964) (Clay II); and Crider v. Zurich Ins. Co., 380 U.S. 39 (1965). For corresponding interest-analytic developments in international choice cases decided since 1939, see, e.g., Steele v. Bulova Watch Co., 344 U.S. 280 (1952); Lauritzen v. Larsen, 345 U.S. 571 (1953); Hellenic Lines, Ltd. v. Rhoditis, 398 U.S. 306 (1970). For other similar analyses of forum power in analogous contexts, see Hoopeston Canning Co. v. Cullen, 318 U.S. 313 (1943); Skiriotes v. Florida, 313 U.S. 69 (1941); Osborn v. Ozlin, 310 U.S. 53 (1940). See also the discussion of state choice-of-law alternatives in Richards v. United States, 369 U.S. 1, 12-13, 15 (1962).

${ }^{58} 440$ U.S. 410 (1979). See infra notes $96-100$ and accompanying text.

${ }^{67}$ The exceptions are chiefly among the workers' compensation cases, in which the Court has avoided consideration of the concerns of nonforum states. See also infra note 78. Brainerd Currie suggested that because the choice-of-law question generally does not arise in compensation proceedings (as is true also of criminal and divorce proceedings), compensation cases cannot be evaluated as "false" conflicts even where they actually present false conflicts; in these cases a state can only apply its own law or remit the parties to another forum. Currie, supra note 10, at 20 n.45, reprinted in B. CuRRIE, supra note 1, at 201 n.45. But this is also roughly the circumstance where a choice of nonforum law would trigger a conditional dismissal on forum non conveniens grounds, in a case in which foreign law would be less generous to the plaintiff. It is equally useful in both contexts to be able to understand whether or not the nonforum sovereign has any interest in regulating the controversy.

ss 449 U.S. 302 (1981).

59 Justice Brennan wrote the opinion for the plurality, in which Justices White, Marshall, and Blackmun joined. 449 U.S. at 304. Justice Powell wrote the opinion for the minority, in which Chief Justice Burger and Justice Rehnquist joined. Id. at 332. Justice Stewart took no part in the case. In view of the fact that only eight of the Justices were sitting, the failure of minimal scrutiny to command a majority would have been without long-term significance, but for Justice O'Connor having assumed Justice Stewart's seat. He had been a long-time member of the minimal-scrutiny majority, see, e.g., Nevada v. Hall, 440 U.S. 410 (1979). Her views are not known. 
a series of cases in which an application of forum law was sustained on the basis of the forum's governmental interests alone, despite challenges on grounds of both fairness and federalism.

These cases are worth a closer view, and the best way to provide it is to single out from among them those particularly difficult cases as to which it might be supposed that unfairness to the regulated party, or disregard of important values of federalism, should have made a difference. These can show in sharper relief the power of an interested state to apply its own laws, free from review for fairness or for deference to principles of federalism.

\section{A. The Nonrole of Fairness}

In considering, first, whether fairness limits the choice of an interested state's laws, one thinks at once of Watson $v$. Employers Liability Assurance Corp. ${ }^{60}$ not only because it has often seemed to commentators an extreme example of the freedom of a forum state to apply its own laws, ${ }^{\text {i1 }}$ but more immediately because we now have it on the highest authority that the result was unfair. In the recent case of Rush $v$. Savchuk, ${ }^{62}$ on a question of personal jurisdiction, the Supreme Court struck down on due process grounds the "functional equivalent" of the direct action statute it had sustained in Watson as a matter of choice of law.

In Rush, Minnesota created a forum for litigation of its resident's tort claim against a nonresident driver by authorizing at-

60348 U.S. 66 (1954).

61 See, e.g., A. Ehrenzweig, A Treatise on the Conrlict of Laws 20 n.33 (1962); Martin, supra note 1 , at $203,207-12$.

2444 U.S. 320 (1980).

es Id. at 333 (Stevens, J., dissenting). But see id. at 330 (Marshall, J.) (disputing that the state attachment procedure was the "functional equivalent" of a direct action statute). To Justice Marshall, Rush and Watson are technically distinguishable. Trial of the tortfeasor would be unfair in Rush while trial of the insurance company would be fair in Watson. Moreover, the tortfeasors in Watson might have been amenable to process in any event had adequate long-arm legislation been available at the forum. But the real question is whether Minnesota in Rush could have founded the litigation on a direct action statute. The Court seemed, by the manner in which it distinguished Watson, to assume that the direct action statute would have passed constitutional muster. Id. at $331 \mathrm{n} .19$. If that is so, the question is whether the technical distinction between the two techniques ought to have made a constitutional difference. I doubt that; those offended by the result under the technique of Seider v. Roth, 17 N.Y.2d 111, 216 N.E.2d 312, 269 N.Y.S.2d 99 (1966), would surely be offended by the result on the same facts under a direct action statute; and those numerous courts and scholars who assumed that both techniques were constitutional held equally plausible views. What makes the constitutional difference, then, is the fact that "minimum contacts" analysis applies in cases like Rush and does not apply in cases like Watson. See also infra note 71. 
tachment of the driver's insurer's obligation to defend and pay any judgment ${ }^{64}$ - the technique of the New York case of Seider $v$. Roth. $^{65}$ The Supreme Court struck down the assertion of jurisdiction over the nonresident for want of "minimum contacts." The Court was vague about the manner in which such a proceeding would be unfair to the tortfeasor; the insurer is the real party in interest in such cases. But the Court concluded that the exercise of jurisdiction did not "comport with 'traditional notions of fair play and substantial justice." "Bs

In Watson, Louisiana also created a forum for litigation of its resident's tort claim against a nonresident, not through the Seider $v$. Roth technique, but by legislating a direct action against the insurer on behalf of the tort victim. ${ }^{67}$ Reasoning that Louisiana had a legitimate interest in its resident's recovery, the Court permitted the direct action to go forward under forum law. ${ }^{68}$ This was in the face of the "no action" clause in the insurance policy, valid under any other relevant state's laws. Louisiana was thus allowed to alter the contractual obligations of one nonresident corporation to another. In Rush, on the other hand, the Court criticized the state court's emphasis upon the state's interest in furnishing a forum for its injured resident, expressing the view that the state court should have concerned itself with the problem of fairness to the defendant. ${ }^{69}$ Although the direct action and Seider mechanisms do differ, the differences scarcely seem of constitutional dimension. ${ }^{70}$

Does all this mean that Rush overrules Watson? Not at all. The true distinction between Rush and Watson is that the Supreme Court employs restrictive scrutiny in personal jurisdiction cases, but minimal scrutiny in conflicts cases. That is a distinction the Court itself has insisted upon, in its own terms, in numerous instances. ${ }^{71}$ This is not to say that the divergence is desirable, ${ }^{72}$

arn. Stat. ANn. § 571.41, subd. 2 (West 1976 \& Supp. 1980).

as 17 N.Y.2d 111, 216 N.E.2d 312, 269 N.Y.S.2d 99 (1966).

68 444 U.S. at 332.

${ }^{67}$ La. Rev. Stat. AnN. § 22:655 (West 1978).

348 U.S. at $72-73$.

69 444 U.S. at 332-33.

70 See supra note 63. It has been suggested that Watson is distinguishable from Rush because in Watson, the forum was also the place of injury. See, e.g., Brilmayer, How Contacts Count: Due Process Limitations on State Court Jurisdiction, 1980 SuP. Cr. REv. 77, 102. But see supra note 47; infra note 168.

71 See, e.g., Allstate Ins. Co. v. Hague, 449 U.S. 302, 321 n.3 (1981) (Stevens, J., concurring) ("the Court has made it clear over the years that the personal jurisdiction and choiceof-law inquiries are not the same"); Rush v. Savchuk, 444 U.S. 320, 325 n.8 (1980) (striking 
only that it is a fact. When constitutional scrutiny is minimal scrutiny, issues of fairness, foreseeability, minimum contacts, federalism, what-have-you, are irrelevant. There are no defenses to the application of an interested state's laws.

The workers' compensation cases form another useful example of the Supreme Court's willingness to tolerate an "unfair" application of an interested state's laws. It is always unfair to employers for courts to exceed the limits of the compensation statute under which the employers operate. That is not simply because of their reliance upon statutory or administrative benefits schedules in maintaining a particular amount of compensation insurance. The compensation system at bottom represents an old but ongoing political compromise. ${ }^{73}$ Enterprises are required to maintain funds for no-fault payments to disabled workers. But the quid pro quo for this forced benevolence is the employers' statutory immunity from suit. ${ }^{74}$ To stand trial on allegations of negligence in the workplace is not only expensive, inconvenient, and bad for business; it also exposes business to substantial verdicts. It is the last thing employers want.

But the ubiquitousness of the employers' statutory immunity from suit may be somewhat misleading. There are differences among state laws, usually judicially developed, that could make all the difference to an employer. Many states permit an employee to sue a third party, such as the manufacturer of a defective machine. ${ }^{75}$ Some states will permit the third party to sue the employer over, thus setting up an end run around the prohibition of

down after-acquired residence's exercise of Seider jurisdiction but reserving judgment as to whether forum as after-acquired residence of plaintiff could, without more, apply its own plaintiff-favoring law); World-Wide Volkswagen Corp. v. Woodson, 444 U.S. 286, 294, 299 (1980) (holding place of injury lacked minimum contacts where law of place of injury could constitutionally be applied); Kulko v. Superior Court, 436 U.S. 84, 98 (1978) ("The fact that California may be the 'center of gravity' for choice-of-law purposes does not mean that California has personal jurisdiction over the defendant."); Shaffer v. Heitner, 433 U.S. 186, 216 (1977) ("This line of reasoning establishes only that it is appropriate for Delaware law to govern the obligations of appellants .... It does not demonstrate that ... [they may be brought] before a Delaware tribunal."); Hanson v. Denckla, 357 U.S. 235, 253 (1958) (“[Florida] does not acquire . . . jurisdiction by being the 'center of gravity' of the controversy .... The issue is personal jurisdiction, not choice of law.").

${ }^{72} I$ argue the contrary position in a work in progress. L. Weinberg, Jurisdiction and Minimal Scrutiny; see infra text accompanying notes 176-82.

t3 W. Malone, M. Plant \& J. Littule, Casbs and Materials on Workers' Compensation and Employment Rights 40 (1980); W. Prosser, Handbook of the Law of Torts $\S 80$, at 531 (4th ed. 1971).

74 W. Malone, M. Plant, \& J. LitTue, supra note 73, at 40.

${ }^{73}$ Id. at 451. 
the statute. ${ }^{76}$ Some states cloak the employer's prime contractor with statutory immunity; others do not. ${ }^{77}$

The Supreme Court's workers' compensation cases-none of which actually raises the issue ${ }^{78}$-make clear that an interested state with pro-employee common law rules can judicially repeal a pro-employer state's employers' immunity provision. The strongest case is probably Carroll v. Lanza. ${ }^{79}$ There the Court assumed, however erroneously, ${ }^{80}$ that it was dealing with a true conflict between a state permitting the employee to sue a prime contractor for damages and a state protecting the prime because the prime was a statutory "employer" and thus potentially liable for compensation. The Court permitted the forum, as the place of injury, to entertain the suit, despite the fact that such an action was barred under the laws of the place of contracting, where the coverage was maintained and the employment relationship was centered. ${ }^{81}$ This was done in the teeth of legislation at the place of contracting vesting exclusive jurisdiction of a claim against an employer's prime contractor in the local compensation board. Yet as strong as the case seems, it is fully sustained by the analysis in Alaska Packers and the holding in Pacific Employers. ${ }^{82}$

\section{B. The Nonrole of Federalism}

If fairness is not a significant check on the application of an interested state's laws, what of principles of comity and federal-

${ }^{78}$ See id. at 460-61 and cases cited therein.

77 This was the supposed conflict of laws in Carroll v. Lanza, 349 U.S. 408 (1955). See infra text accompanying notes 79-81.

${ }^{78}$ It might be thought that in Cardillo v. Liberty Mut. Ins. Co., 330 U.S. 469 (1947), the forum "disregarded the exclusive remedy provision of the Virginia act." R. WEINTRAuB, supra note 1, at 522. But it should be noted that Cardillo was a false conflict case (assuming Virginia, the place of injury, would have been less generous to the injured worker). In any event, only compensation, not damages, was being sought in the forum state, and the forum was both the place of the employment contract and the joint domicile of the parties.

79 349 U.S. 408 (1955).

${ }^{\text {so }}$ See id. at 422-26 (Frankfurter, J., dissenting). The Court's assumption in the Hague case that a true conflict was involved is also questionable. See Allstate Ins. Co. v. Hague, 449 U.S. 302, 306 n.6 (1981); Weintraub, Who's Afraid of Constitutional Limitations on Choice of Law?, 10 Hofstra L. Rev. 17 (1981) (Professor Weintraub made this available to me in manuscript.) See also Landvatter v. Globe Sec. Ins. Co., 100 Wis. $2 d$ 21, 300 N.W.2d 875 (Ct. App. 1980) (superceding case on which the Hague defendants relied).

81349 U.S. 408, 413-14 (1955).

${ }_{82}$ See Crider v. Zurich Ins. Co., 380 U.S. 39 (1965) (holding that a state's attempt to create exclusive jurisdiction over a statutory cause of action need not be given full faith and credit by a sister state). See also Nevada v. Hall, 440 U.S. 410 (1979), discussed infra text accompanying note 96 . 
ism? It might be supposed that the full faith and credit clause would police state choices of law at least to protect important values of federalism.

Yet it is a significant feature of minimal scrutiny in conflicts cases that the full faith and credit clause no longer operates as a discrete instrument of constitutional control, ${ }^{83}$ it merely accompanies the due process clause, or stands in for it, when minimal scrutiny takes place. This is so despite the implication of the clause and the act of Congress implementing it $^{84}$ that full faith and credit might be due to some particular state's legislative acts. This neutralization of the full faith and credit clause was an inevitable consequence of Chief Justice Stone's perception that more than one state might have legitimate regulatory interests in a given matter, ${ }^{\mathbf{8 5}}$ and his conclusion (first reached in Alaska Packers and freed from the doctrinal difficulty of interest-weighing in Pacific Employers) that each such state ought to be allowed to vindicate its own laws and policies in its own courts. ${ }^{88}$

The practical implications of the transformation were substantial. After Pacific Employers, the determinate full faith and credit clause was, for all practical purposes, extinct: the Supreme Court would no longer seek to compel all states to apply some particular state's laws to a particular sort of controversy. The goal of uniformity of decision was relinquished. It became possible for the interested forum to regulate foreign as well as local events. As we have already seen, the interested forum could disregard settled propositions of another interested state's laws. So, in the workers' compensation cases, when the state where the worker is insured vests exclusive jurisdiction over compensation claims in that state's agencies, the jurisdictional provision, while binding there, is not binding elsewhere. The interested forum is free to take jurisdiction. ${ }^{87}$ And so, as in the Watson case, as well as in the compensation cases, the terms of an agreement, however enforceable under the laws of the state where the agreement was made, may be disregarded by the interested forum.

Moreover, after Pacific Employers, as we have seen, an inter-

ss See supra note 4.

s4 28 U.S.C. $\$ 1738$ (1976) ("The Acts of the legislature of any State . . . shall have the same full faith and credit in every court within the United States . . . as they have by law or usage in the courts of such State . . from which they are taken.").

ss Alaska Packers Ass'n v. Industrial Accident Comm'n, 294 U.S. 532, 549 (1935).

se See supra text accompanying notes 40-42.

87 See supra text accompanying notes 81-82. 
ested forum is under no obligation to weigh in the balance the possible interests of a sister state. In view of this, it might be said that principles of comity and federalism are suppressed in testing the power of an interested state.

Extreme examples of the Court's reluctance to control an interested forum's choice of its own law on federalism grounds can be found in Wells $v$. Simonds Abrasive Co. ${ }^{88}$ and in Nevada $v$. Hall. ${ }^{8 \theta}$ In Wells, the plaintiff executrix, unable to effect service of process elsewhere, was forced to file suit in Pennsylvania. ${ }^{\circ 0} \mathrm{Per}$ haps because Pennsylvania law was disadvantageous to her, she brought her case in federal court; ${ }^{21}$ Pennsylvania was one of the few states that would apply its own period of limitation in an action for wrongful death under another state's wrongful death act, even where the foreign statute, as is usual, contained its own limitation period.92 Despite this peculiarity, the Supreme Court affirmed the judgment under Pennsylvania law barring the executrix's wrongful death suit. The suit was timely under the statute sued upon-that of the place of injury, where both she and her decedent had resided.

Of course it was not "unreasonable," in the minimal scrutiny sense, for the federal court to apply Pennsylvania law. Pennsylvania's interest in barring the plaintiff's suit under a statute of limitations aimed at protecting the forum from the trial of stale death claims might be an attenuated one in federal court, but Pennsylvania had an additional substantive interest in protecting its resident manufacturers from late-blooming wrongful death suits. Nor was there any fairness problem in the case, as the Supreme Court has defined conflicts fairness. The plaintiff and her decedent could reasonably foresee that the state where the defendant manufacturer could be found would try the case and apply its own laws protecting the resident manufacturer.

88345 U.S. 514 (1953).

89440 U.S. 410 (1979).

${ }^{80} 345$ U.S. at 519 (Jackson, J., dissenting).

91 But of course a diversity court will follow the choice rules of the forum state. Klaxon Co. v. Stentor Elec. Mfg. Co., 313 U.S. 487, 496 (1941). Theoretically, if the forum state would exercise restraint in applying forum law, so too would the diversity court. See, e.g., Lettieri v. Equitable Life Assurance Soc'y, 627 F.2d 930, 932-33 (9th Cir. 1980). Nevertheless, a federal court may feel constrained to apply forum law more often than the forum would; this may have been part of the problem in Wells.

${ }_{92} \mathrm{Id}$. at 516. Representative cases. are gathered in $3 \mathrm{~J}$. BeAle, supra note 44 , at $\$ \S$ 604.3, 605.1 (1935); A. Ehrenzweig, supra note 61, at 431 n.18 (1962); and R. WeINTraub, supra note 1 , at 60 n. 47 . 
But the case does not seem "reasonable" or "fair" in some further sense. Under our general analytic framework, we would identify the choice of forum law in Wells as raising a problem of federalism. The application of Pennsylvania law seems troubling because of its policy implication that one injured by a defective product in interstate commerce may be deprived of a remedy through the vagaries of interstate litigation - that the rights of an aggrieved person may shift or disappear as that person travels across state lines. ${ }^{\text {98 }}$

Wells thus supports the view that concerns of federalism play no role in constitutional control of state choices of law. But the phrase "concerns of federalism" may admit of a number of meanings. In Allstate Insurance Co. v. Hague, Justice Stevens identified one of these as a respect for the "sovereignty" of the sister states.94 Is there, then, constitutional protection for the state whose sovereignty would be affronted by an application of some other state's law? Such a case would be presented, surely, where a state is a party to the litigation. But, as Justice Stevens himself recognized, there has been no constitutional control in this situation. ${ }^{95}$

Yet it might be supposed that where a state is itself a defendant in another state's courts, the concerns of federalism would be so acute that the interested forum's freedom would have to be circumscribed, not only to apply its own law, but to take the case at all. It might be supposed that even if the full faith and credit clause did not speak to this situation, sovereign immunity or some other common law principle of comity would control.

Thus, I doubt that a more forceful demonstration of the Supreme Court's commitment to minimal scrutiny can be found than the recent case of Nevada v. Hall, ${ }^{86}$ where the concerns of the defendant state were powerfully and specifically invoked, yet were ineffective to impugn the choice of an interested forum's laws. In Hall, a California pedestrian had been injured on a California highway by a driver employed by the University of Nevada. The Supreme Court allowed California to summon Nevada to trial in California courts, to apply California law to the question whether Nevada was entitled to the defense of sovereign immunity, and to decide under California law whether Nevada's liability was unlim-

\footnotetext{
ss See infra part III-A.

- 449 U.S. 302, 320 (1981) (Stevens, J., concurring).

os Id. at 323.

- 440 U.S. 410 (1979).
} 
ited-all in the teeth of Nevada's own statute waiving its tort immunity only in its own courts, and then only to a limit of $\$ 25,000$.

Despite the problem of enforcement and the danger of retaliation, both of which were pointed out by the dissent, ${ }^{97}$ the majority reasoned that California had a legitimate interest in providing full recovery for its resident injured there, and that no principles of federal law limited the power of California to advance this interest. ${ }^{98}$ The result, permitting California to disregard Nevada's localizing and limiting legislation, nevertheless may seem rather startling. The Court's commitment to minimal scrutiny had not been exhibited since its last conflicts case in $1965 .^{98}$ Moreover, it had always been supposed that a state could not be sued in a sister state's courts. The Supreme Court had suggested as much. ${ }^{100}$

Of course, if one assumed the Court would adhere to the minimal scrutiny cases already noted, ${ }^{101}$ the result in Nevada $v$. Hall was quite predictable. But if ever there was a role for a more restrictive scrutiny in the name of federalism, it was in Nevada $v$. $\mathrm{Hall}$, where a state sought from a sister state the dignity of trial in its own courts, or at least trial under the terms of its own waiver of immunity. Yet the Supreme Court rejected the view that comity should limit an interested forum's choice of its own law.

Were it possible for a doubt to remain on the nonrole of federalism in constitutional review of choice of law, that doubt finally would have been laid to rest in the Hague case. ${ }^{102}$ There, seven of the eight sitting Justices rejected Justice Stevens's solitary proposal $^{103}$ that principles of federalism be brought to bear upon state choices of law through review under the full faith and credit clause. Nevertheless, we must pause for a moment at Hague, because it raises a doubt about the future of minimal scrutiny.

\section{The Hague Problem}

In the Hague case, the Court in a plurality opinion by Justice Brennan $^{104}$ permitted Minnesota, the after-acquired residence of the plaintiff widow/administratrix, to treble the liability of the de-

${ }^{97}$ Id. at 429-30 (Blackmun, J., dissenting).

os Id. at $424-26$.

"Crider v. Zurich Ins. Co., 380 U.S. 39 (1965).

100 Western Union Tel. Co. v. Pennsylvania, 368 U.S. 71, 80 (1961) (dictum).

${ }^{101}$ See supra note 82 and accompanying text.

102449 U.S. 302 (1981).

${ }^{105} \mathrm{Id}$. at 320 (Stevens, J., concurring).

104 See supra note 59. 
cedent's insurer, as that liability would be defined under the laws of Minnesota, the only state relevant to the case either at the time the insurance was obtained or at the time the insured-against risk occurred. Both the plurality and the minority-seven of the eight sitting Justices-endorsed in terms the principle of minimal scrutiny for state interest alone. ${ }^{105}$ One might suppose that nothing could better exemplify the settled status of minimal scrutiny. But a closer look reveals that the Court is divided on the issue.

A sense of unfairness in permitting the after-acquired residence to expand the obligations of the defendant-a taint of retroactivity-troubled the Hague Court; all of the Justices felt that under the 1936 case of John Hancock Mütual Life Insurance Co. $v$. Yates, ${ }^{108}$ the state of after-acquired residence could not without further contact with a case regulate the case for its resident's benefit. Justice Brennan's plurality opinion avoided Yates by finding other contacts between the state and the controversy so that he did not have to pitch the case wholly on the residence of the widow. He reasoned that Minnesota was not only the state of her present residence, but also a place where the defendant insurer was doing business; moreover, the decedent had commuted to work there for some years. ${ }^{107}$

Justice Powell's opinion for the dissenters proposed that the constitutional interest analysis should be a two-pronged one, consisting of a fairness inquiry first, followed by an interest inquiry proper. ${ }^{108}$ But the minority was then unable to identify any unfairness in the case-surely a disappointment, having created the prong. The minority found, and Justice Stevens agreed (as did the plurality), that there was no unfairness in the case because the application of Minnesota law had been foreseeable to the defendant. ${ }^{109}$ One who insures the well-being of a driver who commutes to work in Minnesota can foresee that injury and death to the insured might occur there and thus that Minnesota might acquire an interest in the insurer's liability-even though Hague's death had

108449 U.S. at 308 n.10 (Brennan, J.); id. at 336 (Powell, J., dissenting).

108299 U.S. 178 (1936). See supra note 53.

107449 U.S. at 316-18. The relative interests of the concerned states in Hague is the subject of Weinberg, Constitutional Conflicts Cases and the Problem of Relevant Time: A Response to the Hague Symposium, 10 Horstra L. REv. (forthcoming summer 1982).

108449 U.S. at 332-36.

${ }^{109}$ Id. at 336-37 (Powell, J., dissenting); id. at 327-28 (Stevens, J., concurring); id. at 318 n.24 (Brennan, J.). 
not, in fact, occurred there. ${ }^{110}$ The minority then fell back upon the supposed infirmity of the after-acquired residence, an infirmity in the abstract, and concluded that Minnesota had not been an interested state. ${ }^{111}$

Now, with deference, the question of fairness cannot arise until the existence of state power is determined, because it would accomplish nothing to test a noninterested state's laws for fairness. ${ }^{112}$ Thus, despite the minority's attempt to respect the principle of minimal scrutiny in terms, its proposal actually would require that the choice of an interested state's laws be reviewed for fairness. In short, the minority was proposing restrictive scrutiny.

In effect, this was also the proposal of Justice Stevens, except that he would not pause to inquire into state interest at all. He doubted whether any forum state could be said to be a noninterested one; the forum state would always have an interest in the administration of justice in its tribunals. ${ }^{113}$ Thus, four of the Jus-

110 Justice Brennan pointed out that Minnesota courts would not automatically apply the law of the place of injury, id. at $316 \mathrm{n} .22$, but agreed for the plurality that the choice was foreseeable.

111 Id. at 337. In Justice Powell's view, the facts that the insurer did business in the forum state and that the insured worked in the forum state did not support the choice of law either. Id. at 337-40. My own view on the sufficiency of the contacts in Hague may be gleaned from the discussion supra text accompanying notes 52-54. See also Weinberg, supra note 107 .

${ }^{112}$ See supra text accompanying note 27.

113449 U.S. at 326. See also R. LEFLAR, supra note 1, at 212 ("concerns of a justicedispensing court"); A. von Mehren \& D. Trautman, supra note 1, at 255 ("evenhandedness"); Currie, Notes on Methods and Objectives in the Conflict of Laws, 1959 DukE L.J. 171,180 , reprinted in B. CuRRIE, supra note 1, at 177, 186 ("rational altruism"). Although such notions seem to have the effect of transforming every issue into a procedural one, they contribute importantly to resolution of potential equal protection difficulties, as suggested by Judge Burke in Tooker v. Lopez, 24 N.Y.2d 569, 591, 249 N.E.2d 394, 408, 301 N.Y.S.2d 519,538 (1969) (concurring opinion). In dealing with unprovided-for cases, so called, where neither state has an interest, the general interest in evenhandedness can furnish a constitutional solution. Another route to the same result is available, see Sedler, Interstate Accidents and the Unprovided For Case: Reflections on Neumeier v. Kuehner, 1 Horstra L. REv. 125, 138 (1973) (where neither state is interested in the defense, the "common policies" of both states support the plaintiff's claim); these approaches buttress each other.

Also related to Leflar's "justice-dispensing court" would seem to be the "moderate and restrained" interpretation of the reach of forum law proposed by Brainerd Currie in The Disinterested Third State, supra note 11, at 757, and similar concepts. With respect to "comparative impairment" analysis, see People v. One 1953 Ford Victoria, 48 Cal. 2d 595, 598-99, 311 P.2d 480, 482 (1957); Baxter, Choice of Law and the Federal System, 16 Stan. L. Rev. 1 (1963). See generally Restatement (Second) of Conflict of LAws § 6 (1971). These concepts essentially encourage varieties of interest-weighing and are helpful in resolving true conflict cases. 
tices seem prepared to abandon minimal scrutiny. ${ }^{114}$

It becomes of some importance, then, to understand just what advantages minimal scrutiny has offered, and what is at stake should it give way to a more restrictive review of choice of law.

\section{The Virtues of Minimal Scrutiny}

\section{A. National Conflicts Policy}

Certain interrelationships among the Supreme Court's conflicts, jurisdiction, and judgments cases suggest policies that support minimal constitutional control of choice of law. Although such policy considerations do not furnish a wholly consistent or decisive argument in favor of minimal scrutiny, inevitably they must exert important pressures upon the Supreme Court. For, of course, national substantive policies manifest themselves in our current arrangements for private litigation in interstate cases, as a little reflection upon the character and interworkings of our established institutions of interstate litigation will reveal.

There is a peculiar, skew quality in the administration of multistate litigation, a warp amounting almost to a bias. One would have to read in blinkers such cases as International Shoe Co. $v$. Washington, ${ }^{115}$ Pacific Employers Insurance Co. v. Industrial Accident Commission, ${ }^{116}$ Hughes v. Fetter, ${ }^{112}$ Crider v. Zurich Insurance Co., ${ }^{118}$ Van Dusen v. Barrack, ${ }^{119}$ and Fauntleroy v. Lum ${ }^{120}$ not to discern in them a tendency to place governing law at a

\footnotetext{
114 Justice Powell's minority opinion was joined by Chief Justice Burger and Justice Rehnquist. Justice Stevens concurred in the judgment only.

115326 U.S. 310 (1945) (given minimum contacts, state can exercise personal jurisdiction over a defendant who does not reside or cannot be found within its territory).

116 306 U.S. 493 (1939) (interested forum may apply its own law in disregard of laws of interested sister state).

117341 U.S. 609 (1951) (interested forum may not deny benefit of its remedial laws to residents injured in other states) (as explained in Wells v. Simonds Abrasive Co., 345 U.S. 514, 518-19 (1953)); see Currie, supra note 47.

118380 U.S. 39 (1965) (interested forum may take jurisdiction over case pleaded under another state's laws, even where other state has vested exclusive jurisdiction in a local agency).

${ }_{110} 376$ U.S. 612 (1964) (federal interdistrict transfer should not affect choice of law available at plaintiff's chosen forum; law of transferor forum applies). See also Gulf Oil Corp. v. Gilbert, 330 U.S. 501, 508 (1947) (although forum non conveniens available, plaintiff's choice of forum should rarely be disturbed). But see Piper Aircraft Co. v. Reyno, 102 S. Ct. 252 (1981) (not an abuse of discretion to grant forum non conveniens dismissal in international case even though foreign court would not apply American law and foreign law was less favorable to plaintiff).
}

220210 U.S. 230, 237-38 (1908) (erroneous judgment entitled to full faith and credit). 
plaintiff's option. Under these cases, a plaintiff may shop for any favorable forum, may even sue at home, if there are "minimum contacts."121 The chosen forum may then apply its own law; ${ }^{122}$ indeed, it may not withhold its laws so as to discriminate between those of its citizens whose claims arise within and those whose claims arise without the forum state. ${ }^{128}$ The plaintiff's choice of forum will be preserved even where a more concerned state under its own laws has established "exclusive" adjudicatory or legislative jurisdiction over the matter. ${ }^{124}$ Where the plaintiff's choice of forum is defeated by a federal interdistrict transfer, the initial choice of law at the transferor forum will be preserved. ${ }^{128}$ Most importantly, the resultant judgment will. be enforceable in every state-even where it is based on an erroneous choice of law. ${ }^{\mathbf{1 2 6}}$

What policies could support such seeming bias in our institutions of interstate litigation? These arrangements, it seems plausible to suggest, are part of the paraphernalia we employ to regulate a great common market and to rationalize a stubborn federalism. The bias we have identified seems essential to those functions. So it is that the American tort plaintiff, for example-whether the victim of a defective product in interstate commerce or of a careless driver in interstate transportation-generally will not be defeated by territorial limits on state power. ${ }^{127}$ This is one of the ways in which we effectuate policies promoting the safety of the interstate market or of the nation's highways. So it is also that the contract creditor's right generally will be preserved, despite the multistate aspects of a transaction..$^{128}$

We would like to provide as decent protection for the beneficiary of a trust or devise, or the partner to a marriage; it would not comport with a sound federalism to permit settled arrangements, and the expectations built upon them, to fall apart as litigation crosses state lines. ${ }^{129}$ But unfortunately we have not succeeded in

121 International Shoe Co. v. Washington, 326 U.S. 310, 320 (1945).

${ }_{122}$ Pacific Employers Ins. Co. v. Industrial Accident Comm'n, 306 U.S. 493, 502 (1939).

${ }^{123}$ Hughes v. Fetter, 341 U.S. 609, 613 (1951).

${ }^{124}$ Crider v. Zurich Ins. Co., 380 U.S. 39, 42-43 (1965).

125 Van Dusen v. Barrack, 376 U.S. 612, 638-39 (1964).

${ }^{126}$ Fauntleroy v. Lum, 210 U.S. 230, 237 (1908).

${ }^{127}$ See generally A. EHRENZwEIG, supra note 61, at 541-97.

${ }^{128}$ With respect to jurisdiction, see McGee v. International Life Ins. Co., 355 U.S. 220 (1957); with respect to choice of law, see U.C.C. \$ 1-105 (1977); with respect to enforcement of judgments, see Fauntleroy v. Lum, 210 U.S. 230 (1908).

129 This, perhaps even more than the ideal of uniformity of decision, is the great appeal of the "vested rights" theory. See, e.g., Loucks v. Standard Oil Co., 224 N.Y. 99, 110-11, 120 
such cases in matching national litigational institutions to our validating policies. The system does not work very well in cases in which plaintiffs cannot be expected to carry the "right" flag, ${ }^{130}$ and it breaks down when the plaintiff is forced to an unfavorable forum. In such cases, multistate policy must depend for effectuation upon refinements in the common law choice rules at the local level, absent statutory intervention at some level. ${ }^{131}$ Yet conflicts law has not been inadequate to this challenge; the conflicts laws of the several states in fact reveal similar biases to those identifiable in the national system and are key to the functioning of that system: local pro-defendant, invalidating law will often be displaced by law chosen after multistate remedial and validating policies are taken into account. ${ }^{\mathbf{1 3 2}}$

Conflicts law has always reflected the underlying purposes of substantive law; it makes little sense for a state's conflict-of-laws rules to be at cross purposes with the widely shared substantive

N.E. 198, 201-02 (1918) (Cardozo, J.) ("The plaintiff owns something, and we help him to get it. ... The courts are not free to refuse to enforce a foreign right at the pleasure of the judges .... They do not close their doors, unless help would violate some fundamental principle of justice, . . . some deep-rooted tradition of the common weal.").

${ }^{130}$ See, e.g., In re Estate of Barrie, 240 Iowa 431, 35 N.W.2d 658 (1949) (validity of revocation of devise of real property to church successfully challenged by church at situs, in disregard of ruling in favor of relatjves at domicile).

1si Congress has power to regulate the interstate effects of state "acts" and "proceedings." U.S. CoNST. art. IV, § 1. See infra note 156. Under 28 U.S.C.A. \& 1738A (West Supp. 1981), enacted in 1980, a child custody decree meeting the jurisdictional requirements of the act generally may not be modified under the laws of a sister state. Uniform choice rules, to the extent enacted by the states, can displace otherwise applicable state choice rules. E.g., U.C.C. \$ 1-105 (1977). A state will not infrequently enact a local choice-of-law rule in derogation of its common law choice rules. The so-called "borrowing" statutes, for example, refer to the transactional state's limitation period in lieu of the forum's. See generally R. LBFLAR, supra note 1 , at 256-59.

${ }^{132}$ The classic case is Milliken v. Pratt, 125 Mass. 374 (1878), in which the place of making was selected as the choice rule for contracts, as tending to validate them, in part on the ground of commercial convenience. In Milliken, the domestic defense had in any event been repealed after the contract was made. But choice of foreign law to avoid disfavored local defenses is not always sound as legal process; the better resolution is a straightforward overruling of the disfavored position. Compare, e.g., Pevoski v. Pevoski, 371 Mass. 358, 358 N.E.2d 416 (1976) (applying forum law to issue of interspousal tort immunity in action between resident spouses, after abrogating forum's interspousal tort immunity rule) with Miree v. DeKalb County, 433 U.S. 25 (1977) (applying state law to decide third-party beneficiary rights to airport safety under federal contract, on ground that state law better vindicates national safety interest than asserted federal rule). But where forum law is statutory and the court is unable to construe it narrowly, the resort to foreign law may seem preferable to application of the forum's statute. E.g., Offshore Rental Co. v. Continental Oil Co., 22 Cal. 3d 157, 583 P.2d 721, 148 Cal. Rptr. 867 (1978) (en banc). See generally R. LrspLAR, supra note 1, at 212 (which state has "the better law" is a legitimate "choice-influencing consideration"). 
policies reflected in the state's laws generally. ${ }^{13 s}$ Whatever the underlying purposes of substantive law may be, law is by and large intended to be enforced, and the plaintiff is generally an agent of enforcement. Thus, even the traditional conflicts rules reveal biases in favor of the tort victim ${ }^{134}$ and the contract creditor, ${ }^{135}$ as well as biases in favor of the holder of certain settled rights. ${ }^{136}$

Moreover, American substantive law has become increasingly protective of such interests. Since the turn of the century, the burden of statistically inevitable accident, for example, increasingly has been shifted to defendant enterprises and away from injured workers, consumers, and travelers. ${ }^{137}$ The familiar reasoning is that

13s Restatement (Second) of Conflict of Laws § 6(2)(e) (1971) (factors relevant to a choice of law include the basic policies underlying the particular field of law). The policies underlying the law of tort are, inter alia, compensatory, risk-spreading, and deterrent; the policies underlying the law of contract are, inter alia, enabling and compensatory. Section $6(2)(e)$ is thus, essentially, a direction to consider the sovereign's concern for the plaintiff. See also R. Weintraub, supra note 1, at 270-71 ("[The] pervasive trend in tort law [toward risk distribution] suggests a result-oriented presumption for the resolution of true torts conflicts. Apply the law favorable to the plaintiff.").

134 Reference to the place of injury rather than the place of defendant's conduct facilitates recovery where the defendant's conduct was intended to conform with standards acceptable at the place of conduct, as for example in products liability cases after MacPherson v. Buick Motor Co., 217 N.Y. 382, 111 N.E. 1050 (1916). See Restatement of Conplict op LAWS §§ 378, 379 (1934); A. EHRENZWEIG, supra note 61, at 553 (discussing wrongful death: "concern for the plaintiff is . . the ratio of the lex loci rule").

135 Reference to the place of making rather than the place of performance will tend to validate the agreement. See Milliken v. Pratt, 125 Mass. 374 (1878); Restatement of ConFLICT of LAwS $\S 332$ (1934). See also A. EHRENZwEIG, supra note 61, at 465 ("rule of validation" is true rule for choice of law in contracts cases). See generally Lorenzen, Validity and Effects of Contracts in the Conflict of Laws (pts. 1-2), 30 YALE L.J. 565, 655 (1921); Stumberg, Conflict of Laws-Validity of Contracts-Texas Cases, 10 TEx. L. REv. 163 (1932).

156 The laws of the place of celebration of a marriage, see RESTATEMENT OR THE CONFLICT OF LAWS § 121 (1934), would tend to validate the marriage, for couples travel from an invalidating to a validating state to marry. On the other hand, the validity of a devise would seem to enjoy no particular protection under the laws of the place where the decedent died domiciled, id. $\S 306$, nor would the validity of a living trust of personalty under the laws of the situs of the assets, $i d$. $\$ 294(1)$.

${ }^{137}$ One needs only to recall such developments as the emergence of products liability from the early privity-of-contract position of Winterbottom v. Wright, 152 Eng. Rep. 402 (1842), through the negligence claim established in MacPherson v. Buick Motor Co., 217 N.Y. 382, 111 N.E. 1050 (1916), to the several theories of strict liability in tort prevalent today. See Greenman v. Yuba Power Prods., Inc., 59 Cal. 2d 57, 377 P.2d 897, 27 Cal. Rptr. 897 (1963); Restatement (Second) or Torts § 402A (1965). No-fault statutory schemes produce a measure of recovery for victims of motor vehicle accidents in some states, see Keeton \& O'Connell, Basic Protection-A Proposal For Improving Automobile Claims Systems, 78 HARv. L. REv. 329 (1964), and in all states for victims of industrial accidents, see W. Prosser, supra note $73, \S 80$, at 530 . Wrongful death statutes in all states have removed the common law bar to recovery for surviving dependents, see Moragne v. States Marine 
defendants are in the better position to insure against risk and to spread the cost of doing so, and that such risk-spreading, because it is also risk-shifting and remedial, may on the whole be advantageous to interstate commerce. ${ }^{138}$ Similarly, the nationwide enactment of the Uniform Commercial Code, and the character of the Code itself, suggest that much of the law of contracts has become more validating and less preoccupied with the construction of defenses; we expect enforcement of agreements.

As American substantive law has moved toward this more plaintiff-favoring position, American conflicts law has followed suit. The Supreme Court has taken the lead, building the permissive litigational institutions just noted, including the rule of minimal scrutiny in choice of law. Against this background, most of the states have abandoned the traditional choice rules, once thought to be constitutionally required, and have opted for newer approaches. ${ }^{139}$

The new approaches to choice of law have in common a widely noted tendency to result in the application of forum law-in other words, of plaintiff's law. ${ }^{100}$ For whether a court considers the "gov-

Lines, Inc., 398 U.S. 375, 390 (1970), and wrongful death actions are becoming available at common law, e.g., Gaudette v. Webb, 362 Mass. 60, 284 N.E.2d 222 (1972). Direct action statutes in a few jurisdictions now make the proceeds of the tortfeasor's insurance immediately accessible to suit. E.g., La. Rkv. Stat. Ann. § 22:655 (West 1978); Wis. Stat. Ann. § 803.04(2) (West 1977). The bar of contributory negligence has been widely abandoned in favor of comparative fault; the fellow-servant rule is yielding to respondeat superior; charitable and intrafamilial immunities are crumbling. At the same time, the interstate market has become subject to broad federal intervention, both for reasons of health and safety and to police fairness in trading.

138 See G. Calabresi, The Costs of Accidents (1970); A. Ehrenzweig, Negligencz Without Fault (1951); J. Fleming, The Law of Torts 9-14 (3d ed. 1965); Calabresi, Some Thoughts on Risk Distribution and the Law of Torts, 70 YALE L.J. 499 (1961); Morris, Hazardous Enterprises and Risk Bearing Capacity, 61 YALE L.J. 1172 (1952).

139 Weintraub found that 27 states, the District of Columbia, and Puerto Rico have abandoned lex loci delicti as of 1979. R. WeintrauB, supra note 1 , at 305 .

140 See generally R. LEFLAR, supra note 1, at 181-82. Ehrenzweig points out that historically, from a phenomenological point of view, courts have always exhibited forum preference in choice of law. A. Ehrenzwsig, supra note 61, at 309, 314, 350. See also Currie, On the Displacement of the Law of the Forum, 58 CoLum. L. REv. 964, 1027 (1958), reprinted in B. Currie, supra note 1, at 3, 75. Forum preference tends to be disparaged from neutralist points of view, as does plaintiff preference generally, see, e.g., Baxter, supra note 113, at 10-11, 19, or because choice of forum law seems an unprincipled "coverup" for allowing the plaintiff to proceed, e.g., Leflar, Choice of Law: A Well-Watered Plateau, 41 LAw \& CoNTEMP. ProBs. 10, 26 (1977). See also Juenger, Leflar's Contributions to American Conflicts Law, 31 S.C.L. Rev. 413, 419-20 (1980) ("current eclecticism . . . serve[s] as a convenient source of elaborate verbal justifications needed to buttress foregone conclusions"). For a deeper perspective, see $R$. WeInTRAUB, supra note 1 , at 345-46. It is of interest that the United States proposal to the Hague Conference on Private International Law with respect 
ernmental interests"141 of the forum, or such factors"142 as the "policies underlying the particular field of law"14s and the "needs of the interstate . . . system [ ],"144 the modern techniques tend to arrive at plaintiff-favoring solutions for precisely the reasons we have identified in reflecting upon those "interests," "policies," and "needs."

It is possible, of course, that the pendulum is ready to swing back. ${ }^{145}$ The nineteenth-century view that enterprise needs protection from liability may reappear as a vaguely "supply-side" position that "too much" law enforcement hampers production. And given today's crowded court dockets, we may be ready for a legal system in which even contract creditors find it harder to sue or to get to the jury.

But if the Supreme Court is seriously contemplating restricting the reach of an interested forum's law, whether in the name of fairness or federalism or what-have-you, there is no escaping the fact that the validating, risk-spreading, or remedial purposes of prevailing American substantive law will be subordinated pro tanto to the enterprise-protecting policies of the shifting handful of spasmodically idiosyncratic states in which plaintiffs would not choose to litigate some given issue.

Whatever generally rosy light these considerations may shed upon American litigation, they will not fully explain the Court's commitment to minimal scrutiny in conflicts cases. The very poli-

to products liability reads: "The plaintiff should be given the choice of several designated laws." Reese, Products Liability and Choice of Law: The United States Proposals to the Hague Conference, 25 VAND. L. REv. 29, 31-33 (1972). See Ehrenzweig, Products Liability in the Conflict of Laws-Toward a Theory of Enterprise Liability Under "Foreseeable and Insurable Laws" (pt. 2), 69 YALE L.J. 794, 800-03 (1960). Weintraub proposes "a presumption in favor of recovery." $R$. Weintraub, supra note 1 , at 270 . See also D. Cavers, The Chotce-or-LaW Process 139-80 (1965). With respect to plaintiff orientation in contract cases under modern choice approaches, see Leflar, supra, at 24 ("The modern tendency is to sustain the validity of any contract made in good faith by parties in a fairly equal bargaining position if it would be validated by the law of any substantially connected state ...."). U.C.C. $\$ 1-105$ (1977) also will tend to validate contracts. In the absence of a stipulation to the contrary, forum law is mandated, and the plaintiff generally has the choice of forum. In any event, the law of the forum is the Code, which is generally validating and enabling.

${ }^{141}$ Currie, supra note 10 , at 9 , reprinted in B. CURRIE, supra note 1 , at 188; ReSTATEMENT (SECOND) OF CoNfLict of Laws $\S 6(2)(b)$ (1971).

${ }_{142}$ See the seminal enumeration in Cheatham \& Reese, Choice of the Applicable Law, 52 Colum. L. Rev. 959, 978 (1952), the basis of section 6 of RESTATEMENT (SECOND) of CoNFLICT OF LAWS (1971).

14s Restatement (Second) of Conflict of Laws $\S 6(2)(e)$ (1971).

144 Id. § 6(2)(a).

115 See harbingers in Teachout, Book Review, 67 VA. L. Rev. 815, 817 n.11 (1981). 
cies that support minimal scrutiny would have supported restrictive review in Wells $v$. Simonds Abrasive Co., ${ }^{146}$ where the rights of the plaintiff were destroyed because she had to cross state lines to sue. It appears that where these described concerns of federalism collide with the principle of minimal scrutiny in choice of law, the Court will stalwartly jettison a few concerns of federalism in the particular case to save minimal scrutiny generally. Thus, concerns of federalism appear to support minimal scrutiny at their own expense in cases like Wells. This suggests that other considerations came into play in Wells and have also played a role in the firmness of the Court's commitment to minimal scrutiny; to these I will turn in the next section. ${ }^{147}$

More conspicuously, the recent personal jurisdiction cases $^{148}$ seem utterly at odds with the institutions of interstate litigation just described and the concerns of federalism underlying them. The Court's late pronouncements on "minimum contacts" seem to inhabit a policy universe of their own. Although this is not the occasion for a full-dress discussion of these developments, ${ }^{149}$ we have already noted the manner in which the Supreme Court reviews these cases in our brief consideration of Rush v. Savchuk. ${ }^{150}$ "Minimum contacts" scrutiny will limit even the power of an interested state to assert jurisdiction over a nonresident. If the Court were to employ the analytic framework laid out at the outset of this article, it would begin with an interest analysis and follow with an analysis of fairness and federalism concerns; the Court now performs all of these inquiries in jurisdiction cases through "minimum contacts" scrutiny. But it is clear enough that "minimum contacts" scrutiny is restrictive scrutiny, within the meaning of our general framework. Moreover, the later cases are increasingly restrictive, in the sense that a variety of fresh requirements have been imposed on a state's assertion of long-arm jurisdiction. ${ }^{151}$

This does not necessarily mean that the pendulum left dangling a few paragraphs ago already has begun to swing back, and that the conflicts cases shortly may become subject to similar restrictive scrutiny-perhaps even to "minimum contacts" scrutiny-or that the Court has lost sight of the national interest in

${ }^{146} 345$ U.S. 514 (1953). See supra text accompanying notes 88-93.

147 See infra part III-B.

140 See supra note 2.

149 The jurisdiction cases are the subject of L. Weinberg, supra note 72.

150444 U.S. 320 (1980). See supra text accompanying notes 60-72.

${ }^{131}$ See infra text accompanying notes 177-82. 
facilitating litigation for the interstate plaintiff. Rather, in view of the widely noted restrictiveness of the recent jurisdiction cases, it appears that the Court may have been relying exclusively upon jurisdictional control to monitor both jurisdiction and choice of law. ${ }^{152}$ Control of jurisdiction may have seemed preferable to the Court to more direct control of choice of law. The burden of fairness in interstate litigation could be pitched on a single preliminary question of jurisdiction, very much the same question in every case. Some limits could be imposed on the resourcefulness of the forum-shopping plaintiff. The policy problems (and the structural difficulties to which I shall next turn) that arise when restrictions are placed on interstate litigation would be confined to a narrow range. On this view, the seemingly inconsistent turn taken in the jurisdiction cases might best be understood as yet another measure of the Court's strong commitment to minimal scrutiny of choices of law.

\section{B. Structural and Doctrinal Constraints on Supreme Court Su- pervision of Choice of Law}

What has been said thus far suggests that unfairness or federalism problems in the choice of an interested state's laws will not be regulated by the Supreme Court, at least not directly. That was a burden thrown off in Alaska Packers and Pacific Employers, one that the Court has refused to reassume even in some very hard

152 A. von Mehren \& D. Trautman, supra note 1, at 1342; R. Weintraub, supra note 1, at 124. See also Hanson v. Denckla, 357 U.S. 235 (1958), where the Court struck down Florida's assertion of jurisdiction over a nonresident trustee. Florida would have invalidated the trust, valid in every other relevant state and plainly manifesting the intentions of the settlor. In Rush v. Savchuk, 444 U.S. 320 (1980), the Court struck down the assertion of adjudicatory jurisdiction by the state of the plaintiff's after-acquired residence over a nonresident driver. Under the laws of the place of injury and previous joint domicile of the parties, the plaintiff would have been barred by both contributory negligence and the guest statute. Thus, even in the absence of any contacts with the forum state other than the unilateral move of the tort victim there, the tortfeasor could have been exposed to liability from which his own state protected him. See D. CavERS, supra note 140, at 146-47. In Kulko v. Superior Court, 436 U.S. 84 (1978), the Supreme Court barred an exercise of long-arm jurisdiction by the plaintiff's residence, where its laws would have expanded the obligations of the nonresident defendants on an out-of-state contract. Justice Brennan has taken the view that unfairness in choice of law should be taken into account explicitly as a factor limiting assertion of jurisdiction. World-Wide Volkswagen Corp. v. Woodson, 444 U.S. 286, 311 n.19 (1980) (dissenting opinion). In World-Wide, the forum's assertion of long-arm jurisdiction was barred; under its laws, the defendant sellers apparently would have lost a defense of contributory negligence available in design defect cases at the previous joint domicile of the parties. See Lowenfeld \& Silberman, Choice of Law and the Supreme Court: A Dialogue Inspired by Allstate Insurance Co. v. Hague, 14 U.C.D. L. Rev. 841, 851 n.36 (1981). 
cases. An understanding of why the Court abandoned determinate constitutional control-control that would require application of some particular state's laws in a given case-will shed light on the Court's reluctance to impose restrictive scrutiny upon choices of law today.

To require full faith and credit to the laws of some particular state, the Supreme Court would have had to establish a set of constitutional conflicts rules: if the Court were going to make choices, then a way of choosing would have had to be found. The Court could have forced some wholly new approach upon the states. Or it might simply have elevated into constitutional commands the choice rules then prevailing. It was this latter alternative that the Court adopted in such cases as New York Life Insurance Co. $v$. Dodge $e^{15 s}$ and Bradford Electric Light Co. v. Clapper. ${ }^{154}$ Apart from the uniformity this alternative would have seemed to promise, it would have commended itself to the Court as tending to preserve the Court from an extensive and perhaps unwarranted lawmaking effort.

But the disadvantages of the position were soon all too evident. Every case on two-state facts, including every federal diversity case, had suddenly become, at least potentially, a constitutional one. This uninteresting new burden, entailing so questionable a use of Supreme Court resources, might have been borne if only the Court could have brought uniformity of result to interstate cases. But the then-prevailing conflicts rules, no less than the approaches current today, produced results as to which reasonable people could, and did, disagree.

It must have seemed increasingly inappropriate to force all states as a constitutional imperative to apply the laws of the place of contracting, when the Justices could not always agree where that place was. ${ }^{185}$ Moreover, and in part for that reason, it was not clear that the rules the Court had adopted were the right rules. Yet to force the desired uniform result upon the states entailed forcing the increasingly dubious method. This left the states powerless to develop alternate rules or approaches. Meanwhile, the Court found itself under the very obligation it had sought to avoid: the need to construct a federal common law to justify particular forced choices

183246 U.S. 357 (1918).

186286 U.S. 145 (1932).

1ss See, e.g., New York Life Ins. Co. v. Dodge, 246 U.S. 357, $379-81$ (1918) (Brandeis, J., dissenting). 
of law. In this the Court was in the bizarre position of having to second-guess state judges in matters as to which a long course of common law decision, but little constitutional jurisprudence, could guide it. Moreover, Congress could not easily intervene even under the powers granted to it in the full faith and credit clause, ${ }^{186}$ once the choice rules were graven in constitutional bronze.

Most tellingly, the new federal common law remained unpersuasive; there seemed no compelling reason in these cases to require the forum state to defer to some other state's laws. There might be cases-as Justice Brandeis observed in his celebrated Dodge dissent-when the forum would clearly have sufficient interest to ground lawmaking power. ${ }^{157}$ Similar reasoning defined the scope of the police power in commerce clause cases. ${ }^{158}$ And given that power, why should the existence of another interested state make a difference? In any event, as Justice Stone pointed out, literal enforcement of the full faith and credit clause in cases of true conflict would mean that neither interested state could ever apply its own laws in its own courts. ${ }^{169}$

Thus, for doctrinal, structural, and institutional reasons, the Supreme Court could not long remain in the role it had seemed to envisage for itself in the pre-Alaska Packers era. Yet a mere shift from determinate to indeterminate control could not guarantee freedom from all of these difficulties. If the Court was to scrutinize a choice of law not only for interest, within the meaning of the Dick case, ${ }^{160}$ but also for fairness or comity, in the manner of its personal jurisdiction cases, ghosts of the past would inevitably haunt it.

Of course everyone would agree that a losing party should not have been subjected to laws wholly arbitrary as applied to that party. But if a party is within a state's legitimate sphere of interest, application of that state's laws will always be nonarbitrary as

158 "And the Congress may by general Laws prescribe the Manner in which such Acts, Records and Proceedings shall be proved, and the effect thereof." U.S. CoNST. art. IV, 1 .

${ }^{167}$ New York Life Ins. Co. v. Dodge, 246 U.S. 357, 382-83 (1918) (Brandeis, J., dissenting) ("Is the subject-matter within the reasonable scope of regulation? Is the end legitimate? Are the means appropriate to the end sought to be obtained? If so, the act must be sustained ....").

${ }^{158}$ See supra note 26.

159 Alaska Packers Ass'n v. Industrial Accident Comm'n, 294 U.S. 532, 547 (1935) ("literal enforcement of the full faith and credit clause . . . would lead to the absurd result that ... the statute of each state must be enforced in the courts of the other, but cannot be in its own").

${ }^{180}$ Home Ins. Co. v. Dick, 281 U.S. 397 (1930). 
they affect that party and reasonable within our understanding of the requirements of federalism. Thus, to impose further scrutiny upon the choice of an interested state's laws would put the Supreme Court in the position of having to balance what is reasonable against what is more fair or less parochial. This was the sort of challenge to its common law powers that the Court averted when Alaska Packers gave way to Pacific Employers. Just such entanglements as those would enmesh the Court today, if fairness or federalism were to limit the power of an interested state to apply its law to a case.

At the core of the difficulty lies the fact that the Court would have to find reasons why a state with a legitimate need to regulate a controversy should not be allowed to do so. This is precisely the sort of chore the Supreme Court has been declining all along, when it adopted, as well as when it relinquished, determinate full faith and credit, and again when it abandoned interest-weighing. There would be this difference: the Court would not turn for the content of the new federal conflicts rules to traditional choice-of-law rules; it would be forced to a higher level of creativity. The Court that has given us "purposeful availment" in the jurisdiction cases can hardly contemplate such a prospect with enthusiasm.

Of course there are some state actions that do require a more refined scrutiny than "rational basis" scrutiny or interest analysis can afford. ${ }^{161}$ Such state actions will generally be found to have an important characteristic not shared by choices of law. They will make inherently suspect classifications, or raise other urgent and intrinsically important challenges to fundamental rights and values. In contrast, a choice of law in a true conflict case raises only the question which of two well-meaning sister states, with equally plausible but divergent views on a point of law, should be allowed to prevail on the point in a particular case. The challenge to state action in a substantive constitutional case is based on a perceived conflict between that state action and substantive national policy. But the choice of one state's laws over another's fails to impinge upon any substantive national policy. To the extent we can discern any national policy at all concerning choices of law, it counsels us to limit, not strengthen, constitutional control. ${ }^{162}$ Given the expenditure of the Court's creative resources that would be entailed in fashioning law for restrictive review, a nonarbitrary but "unfair" 
choice of law seems inappropriate for such review, now as much as in the past.

The expenditure of the Court's creative resources would indeed be significant. Even if review were limited to the question of fairness and confined to an inquiry concerning foreseeability, we could not say with confidence that the Court would not have to create a substantial body of federal common law, exponentially multiplied in courts below, to deal with that inquiry alone. And we could not confidently assert that such a body of common law would be persuasive or have predictive power. What is "foreseeable" to the corporate defendant doing business in every state?18s Will a state's rules of law have to be codified to provide the necessary specificity or notice? ${ }^{164}$ Does a tortfeasor acting at home foresee that the tort victim's state may govern the tort? ${ }^{165}$ Does it make a difference whether the victim was injured in the tortfeasor's state or the victim's? ${ }^{160}$ If the victim was felled with a motor vehicle or under the surgeon's knife? ${ }^{187}$ Should it matter to

${ }^{183}$ See, e.g., Allstate Ins. Co. v. Hague, 449 U.S. 302, 338 (1981) (Powell, J., dissenting); Rush v. Savchuk, 444 U.S. 320, 328-29 (1980).

${ }^{164}$ Insufficient specificity in the forum state's statutory manifestation of its regulatory interest was thought, in part, to warrant striking down the assertions of personal jurisdiction in Kulko v. Superior Court, 436 U.S. 84, 98 (1978); Shaffer v. Heitner, 433 U.S. 186, 214 (1977); and Hanson v. Denckla, 357 U.S. 235, 252 (1958). See infra note 177.

${ }_{165}$ E.g., Rosenthal v. Warren, 475 F.2d 438, 444 (2d Cir.) (plaintiff allowed full recovery for wrongful death of husband/patient even though negligence of defendant/surgeon occurred at defendant's domicile, where wrongful death statute limited amount of damages), cert. denied, 414 U.S. 856 (1973). See infra text following note 207.

${ }^{166}$ Compare Rosenthal v. Warren, 475 F.2d 438 (2d Cir.) (victim injured in tortfeasor's state), cert. denied, 414 U.S. 856 (1973) with Watson v. Employers Liab. Assurance Corp., 348 U.S. 66 (1954) (victim injured at home). David Cavers argued for a principle of preference in the true conflict case, under which the defendant acting in his own territory ought to have the benefit of his own law. D. Cavers, supra note 140, at 146-48 (1965). See also Neumeier v. Kuehner, 31 N.Y.2d 121, 128, 286 N.E.2d 454, 457-58, 335 N.Y.S.2d 64, 69-70 (1972) (quoting Judge Fuld's second rule in his concurring opinion in Tooker v. Lopez, 24 N.Y.2d 569, 585, 249 N.E.2d 394, 404, 301 N.Y.S.2d 519, 532-33 (1969)) (in true conflict between plaintiff's state and defendant's state, law applied is that of the place of injury).

${ }^{167}$ Here we have scope for a most fecund and uncompelling federal common law. It will be observed that assumpsit-like cases (in which a prior contractual relationship gives rise to a tort duty) are uniquely suited to the approach now influential in some European courts, selecting the law of the sovereign that is the "seat of the relationship." F. SAvignY, A TrEATISE on the Conflict of LaWs 133 (W. Guthrie trans. 2d ed. 1880). See also D. Cavers, supra note 140, at 166, 177. Consider the case of Rosenthal v. Warren, 475 F.2d 438 (2d Cir.), cert. denied, 414 U.S. 856 (1973). There the surgeon and patient entered into a relationship, the metaphysical "seat" of which commentators have overwhelmingly found to be in the surgeon's home state, because the patient went there to be diagnosed and again to be treated by the surgeon. For conflicts purposes, will it make a difference if the diagnosed patient returns indecisively home, then telephones in his decision to undergo surgery? A 
the forum if the place of injury is in some third state? ${ }^{168}$ And do the parties foresee an application of law simply because traditional choice rules once would have led to the application? ${ }^{189}$ What is the time at which foreseeability is measured? Surely if regulation by the forum is not foreseeable at the time of contracting it may become so at the time of breach. ${ }^{170}$ And what of the situation in

constitutional difference? Despite the difficulty of locating it, the existence of a "seat" in assumpsit-like cases may persuade some of the Justices that out-of-state malpractice is a likelier candidate for restrictive review of forum law than out-of-state accident. But suppose a passenger-driver or an employee-employer relationship (wherever entered into) exists between the parties to an out-of-state accident. Would the constitutional result shift? Would that make sense? And what of the important matter of products liability? It seems clear that the place of injury/domicile of the plaintiff not only can, but should, apply its own remedial laws. But that is not because the sales "relationship" has been entered into in that state. There is no ground on which to discriminate between a mail-order and an in-person plaintiff.

168 To continue the products liability example, supra note 167 , should the state that affords recovery to its residents injured at home by defective products purchased within the state, or even products purchased in the defendant enterprise's state, extend protection to its residents injured in some third state? The harder question would be how to deal with residents injured in the defendant's state, the question considered in another context, supra note 166. It would seem that if the plaintiff in Watson v. Employers Liab. Assurance Corp., 348 U.S. 66 (1954), had purchased and used the home permanent while on a visit to Illinois, where the product was manufactured, and injured herself there, in an action in Louisiana against the manufacturer Louisiana should be able to apply its laws to protect her, assuming jurisdiction. Although the forum would have no contact with the case other than as the residence of the plaintiff, and although Home Ins. Co. v. Dick, 281 U.S. 397 (1930), is widely misread to stand for the proposition that such a forum cannot constitutionally apply its own law, it is questionable whether the foreign facts in the hypothetical variant of Watson furnish a legitimate or rational basis for the proposed discrimination among Louisiana residents. The contrary result indeed may be constitutionally required. Hughes v. Fetter, 341 U.S. 609 (1951); see supra note 47. The defendant, moreover, could "foresee" application of Louisiana law, for the same sort of reason the insurer defendant in the Hague case could "foresee" Minnesota law. Putting its product into the stream of commerce, it must have known it might be subject to the law of any state in the country; the fact that the injury did not occur in Louisiana could not alter this assessment of foreseeability. Thus, application of forum law in such a case might survive even a restrictive scrutiny.

165 See Justice Brennan's discussion in Allstate Ins. Co. v. Hague, 449 U.S. 302, 316 n.22 (1981). See also Gordon v. Parker, 83 F. Supp. 40, $42-43$ (D. Mass.) (Wyzanski, J.) ('[D]epartures from the territorial view of torts ought not to be lightly undertaken. ... [T] he lay plaintiff will regard the distinction as involving a personal discrimination against him ... ."), aff'd, 178 F.2d 888 (1st Cir. 1949).

${ }^{170}$ In Clay v. Sun Ins. Office, Ltd., 377 U.S. 179 (1964) (Clay II), the insurer received premiums for two years, mailed from the after-acquired residence of the insured, and the insured-against risk occurred there. At the time the insurer refused to pay, it was clear that the plaintiff's new domicile had acquired interests in the plaintiff's welfare. In Kulko $\mathrm{v}$. Superior Court, 436 U.S. 84, 93-95 (1978), even if the defendant husband believed his support obligations under the New York agreement were governed by New York law, he must have perceived, after his children joined their mother in California, that he might be in breach of some California obligation when he refused to augment payments to take account of the mother's expanded responsibilities for the children. Thus, the Court conceded that 
which foresight could not have affected conduct? ${ }^{171}$

But restrictive review could not be confined to the issue of foreseeability. That is because such limited restrictive scrutiny would prove ineffective to control the very choices of law for which restrictive scrutiny is thought to be appropriate: choices that are unfair though foreseeable, like the choice of forum law in Wells $v$. Simonds Abrasive Co.;72 or unwise, or inappropriate, or parochial, like those in Lilienthal $v$. Kaufman ${ }^{173}$ and in other cases that have drawn from outraged commentators the opinion that they are unconstitutional, like Rosenthal v. Warren ${ }^{174}$ and Allstate Insurance Co. $v$. Hague. ${ }^{175}$ Thus, the Court would be pressed to broaden its search for plausible reasons to limit the power of an interested state to apply its own laws. But because in every case the Court by hypothesis would be reviewing a nonarbitrary, minimally fair state action, its search for limiting principles could produce at best only a common law of prudential considerations, plausible in some cases, less plausible in others, unpersuasive, and lacking in predictive power. At worst, such an effort will produce a jurisprudence of strained formalism, anachronistic territorialism, inconsistency, and paradox. I do not make these gloomy predictions in vacuo. The reader may have recognized that most of these dangers have been realized, more or less, in the personal jurisdiction cases. The very constraints that have thus far operated to deter the Court from restrictive review of conflicts cases surely should have counseled similar caution in the jurisdiction cases. Yet the Court has returned recently to the jurisdiction problem, perversely plunging

California law might be applied to measure the father's obligation.

${ }^{171}$ See Sedler, supra note 54, at 241. See also Chase Sec. Corp. v. Donaldson, 325 U.S. 304,316 (1945).

172345 U.S. 514 (1953). See supra text accompanying notes 88-93.

${ }_{173} 239$ Or. 1, 16, 395 P.2d 543, 549 (1964) (applying incapacitating rule to enable resident defendant to escape obligations to nonresident contract creditor). With Lilienthal, compare Milliken v. Pratt, 125 Mass. 374 (1878), applying foreign law to validate a contract despite a local rule that would protect the resident defendant. See also Reese, supra note 1, at 1597 ("Lilienthal provides a [clear] example of unfairness . . . of due process proportions ....").

${ }^{174} 475$ F.2d 438 (2d Cir.), cert. denied, 414 U.S. 856 (1973). See, e.g., R. WEInTraUB, supra note 1, at 201 \& n.46 (result in Rosenthal "outrageous"); Reese, supra note 1, at 160506 ("[T]here must come a point where the needs of the interstate ... system[] should require a state to subordinate its lesser interests to the far greater interests of a second state. Rosenthal . . . lies well beyond this point.").

175449 U.S. 302 (1981). See, e.g., Reese, The Hague Case: An Opportunity Lost, 10 Hofstra L. Rev. 195 (1981); von Mehren \& Trautman, Constitutional Control of Choice of Law: Some Reflections on Hague, 10 Horstra L. REv. 35 (1981), both appearing after this article went to press. 
more deeply into the "minimum contacts" quagmire. ${ }^{178}$ The later jurisdiction cases exhibit precisely the sort of awkward, ad hoc fashioning of less-than-plausible "reasons" that the Court has so determinedly skirted in conflicts cases.

In attempting to say what exercises of long-arm jurisdiction are foreseeable (or, perhaps in attempting to evaluate the forum's interest), the Court has imported a new and puzzling formalism into interstate litigation, requiring, apparently, a specificity in long-arm legislation that seems in fact to have no genuine function. ${ }^{177}$ But the Court has been unable to confine fairness scrutiny to an inquiry concerning foreseeability, ${ }^{178}$ for precisely the reasons we have already predicted would work to the same effect in conflicts cases. An almost medieval notion of submission to jurisdiction has been the consequence, elaborated in an ungainly jurisprudence of "purposeful availment."179 The International Shoe

176 See the cases on adjudicatory jurisdiction cited supra note 2.

177 In Rush v. Savchuk, 444 U.S. 320 (1980), the Court struck down an assertion of jurisdiction that the state might constitutionally have authorized through formal enactment of a direct-action statute. See id. at 333-34 (Stevens, J., dissenting); Watson v. Employers Liab. Assurance Corp., 348 U.S. 66, 69-74 (1954); supra text accompanying notes 60-72. In Shaffer v. Heitner, 433 U.S. 186 (1977), the Court struck down Delaware's assertion of jurisdiction over nonresident directors of a Delaware corporation in an action alleging mismanagement of the corporation; the Court justified this ruling in part on the ground that Delaware's sequestration statute was not a specific expression of Delaware's regulatory interests, id. at 214. The requisite legislation has since been enacted, Del. Cone Ans. tit. 10, $\$ 3114$ (Supp. 1980), and the Delaware Supreme Court has sustained it, Armstrong v. Pomerance, 423 A.2d 174, 179 (Del. 1980). A similar lack of specificity was thought to justify the result in Kulko v. Superior Court, 436 U.S. 84 (1978); California had failed to create a specific long-arm statute to vindicate its interest in enforcing support obligations owed by nonresidents to residents. Id. at 98. But California's long-arm legislation is intended to give to California courts powers coextensive with the Constitution. Car. Crv. Proc. Code $\$ 410.10$ (West 1973). See also Hanson v. Denckla, 357 U.S. 235, 252 (1958), in which the Court distinguished McGee v. International Life Ins. Co., 355 U.S. 220 (1957), in part on the ground that in the latter, the forum state had enacted specific long-arm legislation for the purpose of vindicating a particular regulatory concern.

${ }^{178}$ See World-Wide Volkswagen Corp. v. Woodson, 444 U.S. 286, 295-96 (1980) (conceding that exercise of jurisdiction might have been foreseeable in Hanson, Kulko, and the case at bar, and rejecting foreseeability as "the criterion").

${ }^{179}$ Every case since Hanson v. Denckla, 357 U.S. 235 (1958), has insisted upon some unilateral act by the defendant by which it "purposely avails itself of the privilege of conducting activities within the forum State," id. at 253. But the insistence has not made the requirement understandable over time. For example, why was the trustee's continuing management of a Florida resident's assets not a "purposeful availment" in Hanson? Though the trustee did not solicit the agreement, as the nonresident insurer did in McGee v. International Life Ins. Co., 355 U.S. 220, 222 (1957), the fact of solicitation could have made no real difference to the result in $M c G e e$, because the state was asserting its interest in regulating the breach, not the formation, of the agreement, id. at 222-23. In Kulko v. Superior Court, 436 U.S. 84 (1978), the defendant sent one child to California at his own expense and then 
preoccupation with convenience to defendants has been indulged at the expense of convenience to plaintiffs in interstate litigation and thus at the expense of underlying national litigation policies. ${ }^{180}$ Yet convenience of defendants has also proven an essentially unhelpful test of jurisdiction; ${ }^{181}$ convenience has given way to an anachronistic new. territorialism, in which principles of federalism require recognition of the continuing importance of state lines, without reference to fairness to, or the convenience of, defendants. ${ }^{182}$

One suspects that these sorts of difficulties are intrinsic to any scrutiny more refined than minimal scrutiny in interstate litigation cases. One has only to look with a cold eye at the jurisdiction cases for a preview of what restrictive scrutiny of choice of law might entail for the administration of interstate justice.

\section{C. "Minimum Contacts" for Conflicts Cases}

\section{If we regard the new territorialism and formalism of the per-}

put his ex-wife to litigation to obtain support for both children, id. at 87-88; why was this not a "purposeful availment" as far as California's adjudicatory jurisdiction was concerned? In Shaffer v. Heitner, 433 U.S. 186 (1977), why was an undertaking to serve as a director of a Delaware corporation not a "purposeful availment" as far as Delaware's adjudicatory jurisdiction was concerned? Id. at 213. Indeed, the purposeful availment component of both Kulko and Shaffer is rendered ludicrously irrelevant to the results by the Court's suggestions that the respective forum states could assert jurisdiction constitutionally by enacting more specific long-arm legislation. See supra notes 164, 177.

180 See supra part III-A.

${ }_{101}$ See, e.g., Rush v. Savchuk, 444 U.S. 320, 328-30 (1980) (assertion of jurisdiction by attachment of tortfeasor's insurer's obligation to defend and pay any judgment impermissible, even though insurer is real party in interest and will pay tortfeasor's litigation expenses). Justice Brennan, dissenting in World-Wide Volkswagen Corp. v. Woodson, 444 U.S. 286, 300-01 (1980), pointed out the futility of the convenience standard today. The courthouse located conveniently next door may lack constitutional adjudicatory power, while one hundreds of miles from home, yet in the defendant's own state, will be able to summon the defendant to appear. See Buckley v. New York Post Corp., 373 F.2d 175, 184 (2d Cir. 1967) (Friendly, J.). In addition, it is becoming increasingly anachronistic to speak of inconvenience. Interstate travel today involves a minimal investment of time and money. Finally, forcing the plaintiff to seek out the defendant, rather than forcing the defendant to come to the plaintiff, seems antithetical to national litigation policies. See supra part III-A. This suggests that at the very least a plaintiff's convenience ought to be taken into account. See von Mehren \& Trautman, Jurisdiction to Adjudicate: A Suggested Analysis, 79 HArv. L. Rev. 1121, 1127-28 (1966).

${ }^{182}$ World-Wide Volkswagen Corp. v. Woodson, 444 U.S. 286, 292-93 (1980) (despite lack of real burden on defendants, "we have never accepted the proposition that state lines are irrelevant for jurisdictional purposes"); Hanson v. Denckla, 357 U.S. 235, 251 (1957) ("restrictions [on personal jurisdiction] are more than a guarantee of immunity from inconvenient or distant litigation. They are a consequence of territorial limitations on the power of the respective States."). 
sonal jurisdiction cases with an unenthusiastic eye, how then would we view application of a "minimum contacts" analysis to conflicts cases? An important recent work has proposed that "minimum contacts" be extended to control state choices of law as well as exercises of adjudicatory power. ${ }^{183}$ It will therefore be of some interest to reflect upon the consequences of importing such scrutiny into constitutional conflicts cases.

There would be the theoretician's satisfaction in having at last a single unified analysis for both jurisdiction and choice of law. But that satisfaction may be gained by employing minimal scrutiny for governmental interest alone in both fields. ${ }^{184}$ "Minimum contacts" would seem to bring some assurance that concerns of fairness or federalism that cannot be vindicated by minimal scrutiny would be given new prominence in constitutional conflicts cases. But there would also be distinct disadvantages.

The Court would have to relinquish a substantially functional inquiry to consider such nonissues as whether the party to suffer adversely from a choice of law has submitted to the legislative jurisdiction of the chosen state by purposefully availing itself of the benefit of its laws; and if so, whether the benefit obtained was commercial or merely domestic. ${ }^{185}$

The Court would have to try to distinguish the well-settled minimal-scrutiny cases unless it was willing to overrule them. Distinctions seem available, but tend to be unconvincing. ${ }^{188}$ It is difficult, for example, to distinguish a minimal-scrutiny case like Clay $v$. Sun Insurance Office, $L t d .{ }^{187}$ from a restrictive-scrutiny case like Kulko v. Superior Court. ${ }^{188}$ In Clay, an action on an insurance policy, the after-acquired residence of the plaintiff insured was permitted to apply its own law in the plaintiff's favor, expanding the contractual time in which suit could be brought. In Kulko, however, an action for additional child support, the residence of the plaintiff mother was not permitted to apply its long-arm statute to

${ }^{183}$ Martin, Personal Jurisdiction and Choice of Law, 78 Mich. L. Rav. 872 (1980). Justices Brennan and Stevens both cited Martin in Allstate Ins. Co. v. Hague, 449 U.S. 302 , 308-09 n.11 (1981) (Brennan, J.); id. at 320-21 n.3 (Stevens, J., concurring).

184 I argue this in L. Weinberg, supra note 72. See also Sedler, Judicial Jurisdiction and Choice of Law: The Consequences of Shaffer v. Heitner, 63 IowA L. REv. 1031, 1033 (1978).

${ }^{185}$ On this last nonissue, see Kulko v. Superior Court, 436 U.S. 84, 97 (1978).

186 See, e.g., distinctions considered supra notes 63,70 .

187377 U.S. 179 (1964) (Clay II).

188436 U.S. 84 (1978). 
enable her to sue the father there. It cannot distinguish the two cases that in Clay, the insured-against risk occurred where the plaintiff resided, for in Kulko the decision of the children to join their mother surely made her residence the place where the need for support arose. ${ }^{189}$ It cannot distinguish the two that in Clay, the insurer contemplated the risk of foreign law by issuing a policy with world-wide coverage and then accepting premium payments sent from the insured's later residence; in Kulko, the father had signed an agreement specifically contemplating performance of his support obligation in California, the mother's residence. ${ }^{190}$

In Clay, it is true, the defendant was licensed to do business in the forum. But that business was unrelated to the subject of the litigation; it could at most buttress the forum's independent interest in recovery for its insured. In Kulko, although the forum was held to lack "minimum contacts" with the defendant father, his actual contact with that state was intimately related to the subject of the litigation: his children were living there with his consent, and he was failing to support them. In any event, in each case a forum with powerful adjudicatory and legislative interests sought in its own courts to assert those interests, foreseeably to the defendant at the time of contracting.

Coupled with the awkwardness of overruling or distinguishing cases like Clay and, as noted earlier, Watson, ${ }^{191}$ would be the awkwardness of disregarding the Court's repeated pronouncements that the interested state, lacking adjudicatory power over a dispute because lacking "minimum contacts," could nevertheless with perfect propriety regulate the same case in another state's courts. ${ }^{192}$

Despite these sacrifices, "minimum contacts" would provide only the bluntest of instruments for conflicts cases. Consider the case in which a defendant waived "minimum contacts" objections to personal jurisdiction. It is reasonable to assume that such a waiver would not be a "purposeful availment."193 It follows that, for want of "minimum contacts," the forum would be unable to apply its own laws in its own courts to favor its own resident as against a defendant within its jurisdiction. Yet the difference be-

189 See 377 U.S. at $180 ; 436$ U.S. at $87-88$.

190436 U.S. at 93 n.6.

191 See supra notes $63,70$.

192 See supra note 71.

${ }^{193}$ For purposes of deciding the choice-of-law issue, the defendant's submission to jurisdiction after commencement of the litigation could hardly be thought to amount to a submission to the laws of the forum. 
tween a "minimum contact" and an impingement upon the state's policy concerns hardly seems to warrant interference in the name of due process with an exercise of state power this well-founded.

An inhibiting aspect of the proposal is that under a regime of "minimum contacts" scrutiny, the Court would have to declare unconstitutional certain quite sound applications of traditional choice rules. As we have seen, the Court has long avoided the question of the constitutionality of the traditional rules in cases where even a minimal scrutiny would have revealed the problem. ${ }^{104}$ But "minimum contacts" scrutiny would render unconstitutional a traditional choice even where interest analysis would fully support it. In World-Wide Volkswagen Corp. $v$. Woodson, ${ }^{195}$ for example, the Court struck down for want of "minimum contacts" the long-arm statute, as applied, of the place of injury. How would the interested place of injury fare, then, if the identical standards applied to a choice of law? ${ }^{188}$

Finally, the proposal would be ineffective to deal with intractable problems in the field. Wells $v$. Simonds Abrasive Co., ${ }^{197}$ for example, would remain uncorrected. The plaintiff forced to a hostile forum probably would have "submitted" to the legislative jurisdiction of the state by resort to its courts in a way that the waiving defendant does not. ${ }^{198}$ The "submission" of the plaintiff who comes to the defendant's forum to sue would leave the Supreme Court helpless to regulate such classic examples of forum parochialism as Lilienthal $v$. Kaufman. ${ }^{199}$ The exercise in restrictive review would have been pointless.

Of course "minimum contacts" scrutiny is a straw man. The question to be addressed, rather, is the feasibility of a simple, direct, and functional restrictive review under the general theoretical

196 See supra text accompanying notes 48-51.

105444 U.S. 286 (1980).

106 The place of injury in World-Wide was "interested" not only in the nonparticularized sense recognized in Carroll v. Lanza, 349 U.S. 408 (1955) (place of injury may compensate plaintiff to protect resident medical creditors, although no resident medical creditors were involved in the case at bar), but in the sense that it would seek to maintain the safety of its roads by deterring the distribution of defective automobiles in interstate commerce. The forum's safety concerns were not discussed in Lanza, Justice Douglas apparently taking the view that the tort claim in that case was purely compensatory.

107345 U.S. 514 (1953). See supra text accompanying notes 90-93.

108 The plaintiff has elected to start up the machinery of a legal system it knows in advance to be concerned with the defendant's welfare. The waiving defendant, on the other hand, is simply relinquishing a right to another place of trial.

109239 Or. 1, 395 P.2d 543 (1964). See supra note 173. 
framework here advanced. As we have seen, policy problems and institutional constraints ${ }^{200}$ suggest the unwisdom of such a course for conflicts cases generally. But would restrictive scrutiny be advisable or feasible for some exceptional conflicts cases?

\section{Restrictive Scrutiny of the Exceptional Case}

In part I of this article, I was able to identify only a few classes of cases for which restrictive scrutiny would be likely to make a difference, cases in which the fairness or federalism issues would remain unresolved by minimal scrutiny for state interest alone. These were:

(1) cases in which the defendant's conduct was authorized or protected by the laws of an interested state where the defendant acted; ${ }^{201}$

(2) cases in which a party moved unilaterally and unforeseeably to the forum state after the transaction or occurrence giving rise to the litigation; ${ }^{202}$

(3) cases in which the validity of a contract, trust, marriage, or devise, or the legitimacy of a birth, is called in question solely because of a contact with an interested invalidating state; ${ }^{203}$

(4) cases in which the plaintiff was forced to a defendantfavoring forum; ${ }^{204}$ and

(5) cases in which the defendant is a state. ${ }^{205}$

Viewing these possibilities in light of discerned national litigation policies, it would seem that cases (1), (2), and (5) do not require exceptional restrictive review. Whatever problems inhere in those cases, the plaintiff, through the choice of forum law, can put herself in a position in which she can obtain justice. That is not

${ }^{200}$ See supra parts III-A \& III-B.

${ }^{201}$ E.g., Watson v. Employers Liab. Assurance Corp., 348 U.S. 66 (1954); Wells v. Simonds Abrasive Co., 345 U.S. 514 (1953); Rosenthal v. Warren, 475 F.2d 438 (2d Cir.), cert. denied, 414 U.S. 856 (1973); Kilberg v. Northeast Airlines, Inc., 9 N.Y.2d 34, 172 N.E.2d 526, 211 N.Y.S.2d 133 (1961).

${ }^{202}$ E.g., Allstate Ins. Co. v. Hague, 449 U.S. 302 (1981); Bernkrant v. Fowler, 55 Cal. 2d 588, 360 P.2d 906, 12 Cal. Rptr. 266 (1961); People v. One 1953 Ford Victoria, 48 Cal. 2d 595,311 P.2d 480 (1957).

${ }^{203}$ E.g., Home Ins. Co. v. Dick, 281 U.S. 397 (1930); Bernkrant v. Fowler, 55 Cal. 2d 588, 360 P.2d 906, 12 Cal. Rptr. 266 (1961); People v. One 1953 Ford Victoria, 48 Cal. 2d 595, 311 P.2d 480 (1957).

${ }^{204}$ E.g., Wells v. Simonds Abrasive Co., 345 U.S. 514 (1953).

${ }^{205}$ E.g., Nevada v. Hall, 440 U.S. 410 (1979). 
such a bad result, not so bad as to warrant exceptional restrictive review. Rosenthal $v$. Warren ${ }^{208}$ is a familiar example of the case (1) situation. That New York, the forum, had an interest in the full recovery of its resident, the plaintiff widow, has not always seemed to commentators sufficient to resolve their doubts about the fairness of permitting her to recover in full against the defendant surgeon. The tortious act-the negligently performed operation causing the death of the plaintiff's husband-took place in the defendant's state, under whose laws the defendant's liability for wrongful death would have been limited to $\$ 50,000 .^{207}$

The proposition that a defendant should be able to rely on his own law when acting in his own territory is an appealing one, but where the defendant injures not a resident of that territory but an outsider (particularly where, as in Rosenthal, he knows the plaintiff is an outsider), that proposition does not merit the status of a constitutional command. It might be suggested that it was inappropriate for the federal court to apply New York law in Rosenthal because New York lacked "minimum contacts" with the defendant surgeon; under current Supreme Court jurisprudence, it is believed that the Rosenthal Court did not have jurisdiction. But it does not follow that its choice of forum state law was unconstitutional.

Case (5) is similar to case (1). The fact that the case (5) defendant is a state simply emphasizes that the case is a true conflict case. There would seem to be no principled reason for disturbing the remedial view of the Supreme Court in Nevada v. Hall, ${ }^{208}$ and every reason of national litigation policy to support it. ${ }^{209}$

Nor does case (2) seem a candidate for exceptional review, although it has probably given the Supreme Court more trouble than any other. Although the Court has dealt with other conflicts in time in a more assured way, ${ }^{210}$ these "unilateral activity" cases are

208475 F.2d 438 (2d Cir.), cert. denied, 414 U.S. 856 (1973).

207 See supra note 166. Restatement of Conflict of LAws $\$ 382$ (1934) limits this territorial protection to the situation in which the defendant is actually required, or at least privileged, to take the offending action.

208440 U.S. 410 (1979).

209 See supra part III-A.

210 With respect to retroactive applicability of current policy, see Ginzburg v. United States, 383 U.S. 463, 466 n.6 (1966) (applying new interpretation of criminal statute to case at bar); Hamm v. City of Rock Hill, 379 U.S. 306, 308 (1964) (pending state convictions abated by enactment of preemptive federal legislation); Steele v. Bulova Watch Co., 344 U.S. 280, 288-89 (1952) (assuming without discussion that foreign law under which defendant acted irrelevant when repealed by time of trial); $E x$ parte Siebold, 100 U.S. 371, 374 (1879) (judicial declaration of unconstitutionality of statute opens prior convictions to col- 
not importantly different from cases in which there has been a post-transaction change in the law. Such cases are troublesome only if one insists upon conceptualizing the time of the transaction as somehow crystallizing or "vesting" the rights of the parties and then freezing them into permanence. But the interests of states concerned at the time of the transaction may, as a practical matter, evaporate by the time of trial, and new state interests may appear.211

Chief Justice Traynor's celebrated opinion in Bernkrant $v$. Fowler $^{212}$ does raise a serious problem, but not because the defendant unilaterally moved to the forum state and then died there. The difficulty in Bernkrant was that the forum state might have invalidated the relied-upon agreement of the parties. Bernkrant thus invokes a case (3) validity concern, only marginally related to the case (2) conflict in time.

Suppose it is the plaintiff that seeks the benefit of a unilateral move rather than the defendant. Cases like Allstate Insurance Co.

lateral attack). See generally Chevron Oil Co. v. Huson, 404 U.S. 97, 106-07 (1971) (discussing standards for application of new federal statutory interpretations).

On the related problem of identifying the policies underlying the laws, the Court does not seem to have done as well, finding the original intention of the legislature dispositive and tending to omit the teleological examination of current functions of the legislation to which interest analysts are accustomed. See, e.g., City of Mobile v. Bolden, 446 U.S. 55, 66 (1980). See also Alexander, The Concept of Function and the Basis of Regulatory Interests Under Functional Choice-of-Law Theory: The Significance of Benefit and the Insignificance of Intention, 65 VA. L. Rev. 1063, 1069 (1979); Hancock, Torts Problems in Conflict of Laws Resolved by Statutory Construction: The Halley and Other Older Cases Revisited, 18 U. TORONTO L.J. 331, 331 \& n.5 (1968) (purposive theory of meaning too trite to require citation). But see Brilmayer, Interest Analysis and the Myth of Legislative Intent, 78 Mich. L. Rev. 392 (1980) (critique of interest analysis based on the assumption that it is restricted to literal and originalistic statutory construction). See generally Brest, The Misconceived Quest for the Original Understanding, 60 B.U.L. Rev. 204 (1980).

At a further remove are questions of the scope of policy analysis in interpretation of laws. The Supreme Court has brought current economic policies to bear on the applicability of a statute purporting to regulate only tort duties. See Hellenic Lines, Ltd. v. Rhoditis, 398 U.S. 306, 310 (1970). There is a heightened need for comity in the international case, however. Lauritzen v. Larsen, 345 U.S. 571, $577-78$ (1953). In the Protection of Trading Interests Act, 1980, ch. 11, Great Britain has acted to enable British nationals to recover damages paid in excess of compensation under Sherman Act judgments. Id. § 6(1)(a), (b). See generally Baade, Foreword, Symposium on New Trends in the Conflict of Laws, 28 LAw \& CoNTRMP. Probs. 673 (1963); Trautman, The Role of Conflicts Thinking in Defining the International Reach of American Regulatory Legislation, 22 OHIo ST. L.J. 586 (1961).

211 See, e.g., Milliken v. Pratt, 125 Mass. 374, 383 (1878). See also Lowenfeld \& Silberman, supra note 152, at 858 (remarks of Professor Lowenfeld). See generally R. WEINTRAUB, supra note 1 , at 274 .

${ }^{222} 55$ Cal. 2d 588, 360 P.2d 906, 12 Cal. Rptr. 266 (1961). Traynor was not yet Chief Justice when he wrote this opinion. 
v. Hague ${ }^{213}$ and Clay v. Sun Insurance Office, Ltd. ${ }^{214}$ are in this category. The interested state ought to be permitted to bestow new rights on its new resident, if the extraterritoriality of the occurrence in issue does not affect the quality of the forum state's interest-even if this would require, as it did in both Hague and Clay, invalidating a contract term.

It must be remembered that under the laws of every state, virtually identical claims would lie against every defendant, assuming jurisdiction. The "thou shalt nots" are perfectly obvious, and there is little to surprise a defendant in them. It is the defense he has discovered that surprises and delights him. Thus, in the Hague case, the insurer could scarcely be surprised by a law requiring it to pay the amounts contracted for by the plaintiff's decedent. Rather, the stipulation in the insurance policy (a contract of adhesion) that would have cut the paid coverage by two-thirds was surprising to all concerned, and several of the Justices in Hague intimated that the defense was inequitable. ${ }^{236}$ Similarly, in Clay, the insurer could scarcely pretend ignorance of the fact that its policy term providing only twelve months in which suit could be brought on the policy would be unenforceable as against public policy in several states. ${ }^{216}$ Solicitude for defendants in these after-acquired residence cases, or concern for their expectations, will rarely survive examination.

It is unfortunate, then, that all of the Justices in Hague were of the opinion that the widow's after-acquired residence lacked full legislative power. ${ }^{217}$ The Hague position on the point may be salvageable, however; the plurality did hold the after-acquired residence to be at least "relevant," and in ruling for the widow/administratrix, relied in part on that state's interest in full recovery for its new resident, ultimate beneficiary of the decedent's estate. ${ }^{218}$

Cases (3) and (4) are cases in which multistate policies, generally validating and remedial, may be frustrated in the multistate case; these cases thus seem attractive candidates for exceptional restrictive review. Good examples of case (3) would include Bern-

213449 U.S. 302 (1981).

214377 U.S. 179 (1964) (Clay II).

215449 U.S. at 305 n.3 (Brennan, J.); id. at 328 n.18 (Stevens, J., concurring).

116 Clay v. Sun Ins. Office, Ltd., 363 U.S. 207, 215-16 (1960) (Clay I) (Black, J., dissenting).

217 See supra text accompanying notes 106-13.

218 449 U.S. at 318-19. 
krant $v$. Fowler, ${ }^{219}$ in which the promisor moved to an invalidating state and then died, and Lilienthal $v$. Kaufman, ${ }^{220}$ in which the promisor, who had previously been declared a spendthrift by the forum, knowingly ventured out from his own incapacitating state to take a captive from California "down the road to insolvency" with him. ${ }^{221}$ A good example of case (4) is Wells $v$. Simonds Abrasive Co.;22 Lilienthal is also a case in which a plaintiff was deprived of recovery because forced to an unfavorable forum.

Yet very probably even these cases should not be mad. sxceptions to the general rule of minimal scrutiny of choices of law. There is, of course, the obvious objection that to make exceptions of these cases would be to import a new semblance of "vested rights" theory into conflicts law. ${ }^{223}$ There is the burden of explaining why plaintiffs' rights "vest" and defendants' rights do not. ${ }^{224}$ And there is the further risk that review of these sorts of cases would result in seemingly determinate rulings, capable of gross misapplications in courts below.

There is also the technical but interesting point that such cases can be made exceptions only if we recognize one exception at a time. Permitting multiple exceptions would create cases in which neither interested state would have lawmaking power. Suppose, for example, that the widow in the Wells case had a clear right under the laws of her own state to recover for the death of her decedent, injured there. Forced to sue at the place of manufacture, she will lose this right. The Supreme Court therefore finds this an appropriate case for exceptional case (4) restrictive review. But now suppose that the widow's home state were trying the case, the manufacturer having conveniently waived objections to personal jurisdiction. If there were a further exception to minimal scrutiny for cases falling in the class of case (1), the home state constitutionally could not apply its law to expand the obligation of the defendant manufacturer who had acted in his own territory and who would thus be entitled to his domestic statute of limitations. Given exceptions for both case (1) and case (4), neither state would have power to regulate a case like Wells.

\footnotetext{
210 55 Cal. 2d 588, 360 P.2d 906, 12 Cal. Rptr. 266 (1961).

220239 Or. 1, 395 P.2d 543 (1964).

${ }^{221}$ Id. at $25,395 \mathrm{P} .2 \mathrm{~d}$ at 553 (Goodwin, J., dissenting).

${ }^{222} 345$ U.S. 514 (1953). See supra text accompanying notes 90-93.

${ }^{223}$ See supra note 129.

224 See generally supra part III-A, specifically text accompanying notes 127-36 and note 129. See also supra text accompanying notes 90-98, 215-16.
} 
Compounding this difficulty is the fact that we could not hope to confine restrictive review to a single exclusive exceptional category of cases. Fact patterns overlap. In Bernkrant v. Fowler, ${ }^{225}$ the problem of the contract's validity or enforceability co-exists with the problem of the after-acquired residence of the decedent; an exception carved out to give restrictive scrutiny to a choice of invalidating law might be construed in later cases to govern all unilateral-move situations. Similarly, in Wells, the problem of the forced forum overlaps the problem of the defendant acting in his own territory.

On balance it appears unwise to step out in such high wind on this particular slippery slope. The appropriate level for constitutional review of state choices of law is minimal scrutiny for state interest alone.

\section{ENvoI}

The reader may feel I have been advocating a bleak, Hobbesian federalism in which "social jingoism"226 provides the rule of law, and each state selfishly chooses to apply its own laws to favor its own residents, while the Supreme Court persists in tolerating affronts to widely-shared policies like that occasioned by the choice of forum state law in Wells $v$. Simonds Abrasive Co. It is indeed tempting to suggest an exception to minimal scrutiny for the hardest cases-cases in which, as in Wells, the plaintiff has been forced to an uncongenial forum, or in which a party's settled status or expectation will be lost through the vagaries of interstate litigation.

But in the general run of cases we may take comfort in remembering that we are not without the resources of the common law. It is preeminently for the genius of the common law to struggle toward solutions of the many problems of fairness and comity that arise in the administration of conflicts cases. In a case like Wells, to continue with that example, a state is not without power today to take the "moderate and restrained" its own law that the Supreme Court would not force it to take.

${ }_{225} 55$ Cal. 2d 588, 360 P.2d 906, 12 Cal. Rptr. 266 (1961). See supra text accompanying note 212.

${ }^{228}$ DeMateos v. Texaco, Inc., 562 F.2d 895, 902 (3d Cir. 1977) (Gibbons, J.) ("a variety of social jingoism, which presumes that the 'liberal purposes' of American law must be exported to wherever our multinational corporations are permitted to do business"), cert. denied, 435 U.S. 904 (1978).

${ }^{227}$ See Currie, supra note 11, at 757. 
Today a state in such a position could adopt any one of a number of proposed solutions for true conflicts cases, ${ }^{228}$ all of which would result, in a case like Wells, in allowing the plaintiff to try to prove her case.

But just as the choice of law in the Wells case was the wrong choice the Supreme Court's decision sustaining the choice was the right decision. There are no constitutional limits on the choice of an interested state's law, and there ought to be none.

"But sometimes the path that we are beating out by our travel is more important to the future wayfarer than the place in which we choose to lodge."229 Whether or not the reader has followed the road with me to the conclusion I have reached, I hope that the theoretical framework that has been used here will bring some clarification to the subject of constitutional control of choice of law.

${ }^{228}$ See, e.g., Offshore Rental Co. v. Continental Oil Co., 22 Cal. 3d 157, 164-65, 583 P.2d 721, 725-26, 148 Cal. Rptr. 867, 871-72 (1978) (“comparative impairment" analysis); for other techniques, see supra note 113.

${ }^{229}$ First Nat'l Bank v. United Air Lines, Inc., 342 U.S. 396, 398 (1952) (Jackson, J., concurring). 